\title{
Synthesis and application of non- bioaccumulable fluorinated surfactants: a review
}

\author{
Rong Zhou ${ }^{1,2}$, Yong Jin ${ }^{1,2^{*}}$, Yichao Shen ${ }^{1,2}$, Peng Zhao ${ }^{1,2}$ and Yutang Zhou ${ }^{1,2}$
}

\begin{abstract}
Due to negative effects of conventional fluorinated surfactants with long perfluorocarbon chain $\left(C_{x} F_{2 x+1}, x \geq 7\right)$ like perfluorooctanoic acid (PFOA) and perfluorooctane sulfonate (PFOS), these conventional long perfluorocarbon chain surfactants have been restricted in many industrial applications. Nowadays, their potential non-bioaccumulable alternatives have been developed to meet the requirements of environmental sustainable development. In this paper, the recent advances of potential non-bioaccumulable fluorinated surfactants with different fluorocarbon chain structures, including the short perfluorocarbon chain, the branched fluorocarbon chain, and the fluorocarbon chain with weak points, are reviewed from the aspects of synthesis processes, properties, and structure-activity relationships. And their applications in emulsion polymerization of fluorinated olefins, handling membrane proteins, and leather manufacture also are summarized. Furthermore, the challenges embedded in the current nonbioaccumulable fluorinated surfactants are also highlighted and discussed with the hope to provide a valuable reference for the prosperous development of fluorinated surfactants.
\end{abstract}

Keywords: Non-bioaccumulable fluorinated surfactants, Synthesis, Structure-activity relationship, Application

\section{Introduction}

Fluorinated surfactants, acting as special surfactants, are composed of the hydrophilic polar head group and the oleophobic and hydrophobic fluorocarbon tail chain, where at least one hydrogen is replaced by fluorine in their hydrophobic tail. In general, compared with conventional hydrocarbon surfactants, fluorinated surfactants display some unique properties due to characteristics of the fluorine element. For instance, owing to the extremely strong electronegativity of fluorine, both the strong fluorine-carbon bond and the "shielding" effect of fluorine atoms on carbon-carbon bonds provide the outstanding thermal and chemical stability for fluorinated surfactants [1-3]; and the lower polarizability of fluorine compared to hydrogen results

\footnotetext{
*Correspondence: jinyong@cioc.ac.cn

'Key Laboratory of Leather Chemistry and Engineering of Ministry of Education, Sichuan University, Chengdu 610065, China

${ }^{2}$ National Engineering Laboratory for Clean Technology of Leather Manufacture, Sichuan University, Chengdu 610065, China
}

in weaker attractive intermolecular forces, endowing fluorocarbon chains to hydrophobic-oleophobic properties as well as fluorinated surfactants to higher surface activity $[4,5]$. Particularly in the aspect of surface activity, fluorinated surfactants can effectively reduce the surface tension of their aqueous solutions at a very low concentration, with the minimum surface tension of around $15-20 \mathrm{mN} / \mathrm{m}$ [6]. Hence, since fluorinated surfactants were unexpectedly discovered in the 1950s [7], their application potentials and developments have attracted extensive attentions. Various types of fluorinated surfactants now are widely used in many fields including cosmetic [8], textile, leather [9, 10], coating [11], fire-fighting foam [12-14], solar cell [15], and biomedicine [16] etc., which represents a multibillion dollar industry [7].

The most commonly manufactured and used fluorinated surfactants are these long perfluorocarbon chain $\left(\mathrm{C}_{\mathrm{x}} \mathrm{F}_{2 \mathrm{x}+1}, \mathrm{x} \geq 7\right)$ surfactants, such as perfluorooctanoic 
acid (PFOA), perfluorooctane sulfonate (PFOS) and their derivatives. Nevertheless, many studies have revealed that these long perfluorocarbon chain surfactants are persistent in the natural condition, toxic and bioaccumulative in the organism [17-20] because of the very stable C-F bond which is not easy to be degraded under enzymatic or metabolic decomposition [21]. For example, the half-life of PFOA in humans is 3.26 years [22], and these long perfluorocarbon chain surfactants have been detected in the human blood all over the world [23]. As a consequence, long perfluorocarbon chain surfactants are been listed as persistent organic pollutants (POPs) under Stockholm Convention in 2009 and are subsequently restricted in production and utilization in many fields [19].

For above reasons, researchers and commercial companies have developed potential non-bioaccumulable alternatives of long perfluorocarbon chain surfactants to meet the requirements of environmental sustainable development. For example, since 2003, 3 M Company has produced a series of shorter-chain homologue replacements based on $\mathrm{C} 4$ chemistry, such as perfluorobutane sulfonic acid [24]. In this review, according to the difference of the fluorocarbon chain structure, three kinds of fluorinated surfactants (as seen in Fig. 1) which are considered to be potentially non-bioaccumulable [25-27], including 1) surfactants with the short perfluorocarbon chain $\left.\left(C_{x} F_{2 x+1}, x \leq 6\right), 2\right)$ surfactants with the weak points on the fluorocarbon chain, 3) surfactants with the branched fluorocarbon chain, are mainly focused. Their synthetic processes and properties, such as surface activity, wettability, and $\mathrm{pH}$ and salt resistance, are briefly described, and some structure-activity relationships are analyzed. Additionally, their applications in emulsion polymerization of fluorinated olefins, handling membrane proteins, and leather manufacture are summarized, and the future development direction is prospected.

\section{Synthesis of non-bioaccumulable fluorinated surfactants}

Prior to specific description, in order to facilitate readers to understand the research progress of nonbioaccumulable fluorinated surfactants, we provide surface activity parameters, including the critical micelle concentration $(\mathrm{CMC})$ and the surface tension at CMC $\left(\gamma_{\mathrm{CMC}}\right)$ of some representative perfluorooctyl surfactants in Table 1, such as PFOA, sodium perfluorooctanoate (NaPFO), ammonium perfluorooctanoate (APFO), ammonium perfluorooctane sulphonate (APFOS) and potassium perfluorooctane sulphonate (KPFOS). Moreover, serum elimination half-lives of some fluorinated surfactants are shown in Table 2.

\subsection{Surfactants with short perfluorocarbon chain}

Among the non-bioaccumulable alternatives of long perfluorocarbon chain surfactants, the short perfluorocarbon chain surfactants (here, the length of short perfluorocarbon chain is less than or equal to C6) are focused by a large number of researches and reports. These short perfluorocarbon chain surfactants present potential non-bioaccumulation [40, 41]. For example, compared with PFOA (about 3.26 years), the half-live of perfluorobutane sulfonic acid is only 24 and 46 days in male and female human, respectively [22, 24].

However, with perfluorocarbon chain shortening, the surface activity of the short perfluorocarbon chain surfactants also decreases. Generally, the hydrocarbon moieties are introduced into these surfactant molecules to further increase the hydrophobicity and improve the surface activity. Lehanine et al. [42] synthesized a perfluorinated hexyl cationic fluorinated surfactants based on isourea, in which the condensation of a diisopropylcarbodiimide and a fluoroalkyl alcohol was used to obtain a fluorinated diisopropylisourea intermediate and then the intermediate reacted with the hydrohalogenated acid $(\mathrm{HX}, \mathrm{X}=\mathrm{Cl}$ or $\mathrm{Br})$ to yield a salt $\left(\left[\left((\mathrm{CH} 3)_{2} \mathrm{CHNH}\right)_{2} \mathrm{COCH}_{2} \mathrm{CH}_{2}\left(\mathrm{CF}_{2}\right)_{5} \mathrm{CF}_{3}\right][\mathrm{X}], \mathrm{C} 8 \mathrm{IF}-\mathrm{X}, \mathrm{X}=\right.$ $\mathrm{Cl}$ or $\mathrm{Br}$ ) with surface activity. Since the perfluorinated hexyl and the hydrocarbon moiety can together improve hydrophobicity of surfactants, the prepared surfactants showed higher surface activity. And the $\gamma_{\mathrm{CMC}}$ of C8IF-Cl and C8IF- $\mathrm{Br}$ were 19.2 and $20.7 \mathrm{mN} / \mathrm{m}$ at $25^{\circ} \mathrm{C}$, respectively. Moreover, since the hydration between the bigger size counter ion with water was weaker, decreasing the electrostatic repulsion between surfactant molecules [43], the (a)

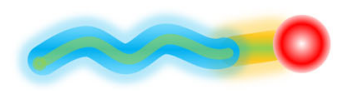

Short Fluorocarbon Chain (b)

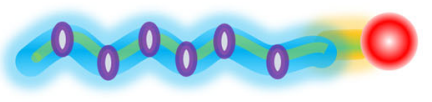

0 Weak point (c)

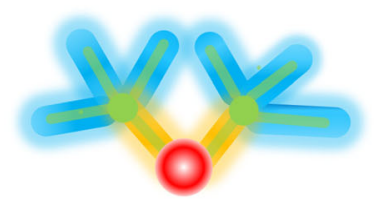

Hydrophilic group

Fig. 1 Simplified schematic illustration of non-bioaccumulable fluorinated surfactants with different fluorocarbon chain structures: a the short perfluorocarbon chain; $\mathbf{b}$ the fluorocarbon chain with weak points; $\mathbf{c}$ the branched fluorocarbon chain 
Table 1 CMC and $\gamma_{C M C}$ of some perfluorooctyl surfactants

\begin{tabular}{llll}
\hline Surfactants & $\begin{array}{l}\mathbf{C M C} \\
(\mathbf{m m o l} / \mathbf{L})\end{array}$ & $\begin{array}{l}\boldsymbol{Y}_{\mathbf{C M C}} \\
(\mathbf{m N} / \mathbf{m})\end{array}$ & References \\
\hline PFOA & 12.3 & 19.51 & {$[28]$} \\
NaPFO & 36 & 24.6 & {$[29]$} \\
APFO & 8.75 & 37.7 & {$[30]$} \\
APFOS & 5.5 & 27.8 & {$[31]$} \\
KPFOS & 8 & 34.5 & {$[31]$} \\
\hline
\end{tabular}

CMC of C8IF-Br $(0.211 \mathrm{mmol} / \mathrm{L})$ was smaller than that of C8IF-Cl (1.421 mmol/L).

Shin et al. [44] designed and synthesized a kind of environmentally benign anionic hemi-fluorinated surfactants with different short perfluorocarbon chains. In detail, alkyl iodides with different fluorocarbon chain length reacted with the phenylvinylsulfonate to form phenylsulfonates using a $\mathrm{Zn} / \mathrm{CuI}$ mediated Michal-type addition reaction in imidazolium ionic liquids. Then, their potassium salts $\left(\mathrm{CF}_{3}\left(\mathrm{CF}_{2}\right)_{\mathrm{n}}\left(\mathrm{CH}_{2}\right)_{4} \mathrm{SO}_{3} \mathrm{~K}, n=0,1,2\right.$ or 3) were obtained successfully by hydrolyzing phenylsulfonates with $\mathrm{KOH}$ in ethanol/water. To avoid the byproduct (phenol), the synthesis method was optimized by replacing the phenylvinylsulfonate with the ethyl vinsulfonate to achieve same proposed products. Compounds $\mathrm{n}=0$ and 1 containing shorter perfluorocarbon chains cannot effectively decreased surface tension of their aqueous solution $\left(\gamma_{\mathrm{CMC}}\right.$ of about $\left.50 \mathrm{mN} / \mathrm{m}\right)$. While with the increase of fluorocarbon chain length, compounds $n=2$ and 3 showed higher surface activity, whose $\gamma_{C M C}$ were 21.8 and $17.7 \mathrm{mN} / \mathrm{m}$, respectively, at their
CMCs of 5561 and $4681 \mathrm{mg} / \mathrm{L}$, respectively. It was worth noting that although compounds $\mathrm{n}=2$ and 3 had stronger ability to reduce surface tension, their CMCs were approximately 10-100 times higher than that of most reported non-bioaccumulable fluorinated surfactants [45, 46], suggesting that higher costs are needed to achieve the desired effect.

In order to further improve the hydrophobicity of short perfluorocarbon chain surfactants, researchers also attempt to introduce two hydrophobic chains into a surfactant molecule. One of the schemes is to design a surfactant bearing a short perfluorocarbon chain and a hydrocarbon chain, namely the hydro-fluorocarbon hybrid surfactant. Kang et al. [47] synthesized a series of hybrid sulfonate fluorinated surfactants $\left(\mathrm{F}\left(\mathrm{CF}_{2}\right)_{2} \mathrm{CH}_{2} \mathrm{OCH}_{2} \mathrm{CH}\right.$ ($\left.\mathrm{SO}_{3} \mathrm{Na}\right) \mathrm{CH}_{2} \mathrm{O}\left(\mathrm{CH}_{2}\right)_{x} \mathrm{H}, \mathrm{F}_{2} \mathrm{H}_{\mathrm{X}}, \mathrm{x}=2,4,6$ or 8$)$ using glycidyl ethers with different alkyl chain length, pentafluoropropanol (the shortest fluorocarbon chain) and chlorosulfonic acid as raw materials. The results showed that with the increase of alkyl chain length, surface activity of synthesized surfactants increased. $\mathrm{F}_{2} \mathrm{H}_{8}$ had the highest surface activity in $\mathrm{F}_{2} \mathrm{H}_{\mathrm{X}}$ when alkyl chain length of 8 , and the $\gamma_{\mathrm{CMC}}$ was $31.9 \mathrm{mN} / \mathrm{m}$ at CMC of $0.1 \mathrm{mmol} / \mathrm{L}$. Yang et al. [48] reported a pyridine-based hydro-fluorocarbon hybrid surfactants $\left(\left[\mathrm{CF}_{3}\left(\mathrm{CF}_{2}\right)_{5} \mathrm{CH}(\mathrm{OH}) \mathrm{pyC}_{\mathrm{n}} \mathrm{H}_{2 \mathrm{n}+1}\right][\mathrm{Br}], n=8,10,12,14\right.$ or 16) with longer alkyl chains. With the increase of alkyl chain length (n from 8 to 16), CMC decreased gradually from $16.4 \times 10^{-3}$ to $1.3 \times 10^{-3} \mathrm{mmol} / \mathrm{L}$ but $\gamma_{\mathrm{CMC}}$ increased gradually from 16.27 to $20.76 \mathrm{mN} / \mathrm{m}$, indicating that a suitable alkyl chain is important for these hydro-fluorocarbon hybrid surfactants to obtain a better surface activity.

Table 2 Serum elimination half-lives of some fluorinated surfactants (KPFOS, PFOA, perfluoroheptanoic acid (PFHA), perfluorohexanoic acid (PFHxA), potassium perfluorobutylsulfonate (KPFBS), ammonium 2,3,3,3-tetrafluoro-2-(heptafluoropropoxy) propanoate acid (GenX) and ammonium 4,8-dioxa-3H-perfluorononanoate (ADONA)) in female (F) and male (M) rats, monkeys and humans

\begin{tabular}{|c|c|c|c|c|}
\hline \multirow[t]{2}{*}{ Surfactants } & \multirow[t]{2}{*}{ Sex } & \multicolumn{3}{|c|}{ Serum elimination half-lives } \\
\hline & & Rats & Monkeys & Humans \\
\hline \multirow[t]{2}{*}{ KPFOS $\left(\mathrm{C}_{8} \mathrm{~F}_{17} \mathrm{SO}_{3} \mathrm{~K}\right)$} & $\mathrm{F}$ & $7.99 \pm 4.94 \mathrm{~d}[32]$ & $110 \pm 15 d[32]$ & 5.9 years [22] \\
\hline & M & 38 d [32] & $131 \pm 7 d[32]$ & 5.4 years [22] \\
\hline \multirow[t]{2}{*}{$\mathrm{PFOA}\left(\mathrm{C}_{7} \mathrm{~F}_{15} \mathrm{COOH}\right)$} & $\mathrm{F}$ & $1.9 \pm 0.7 \mathrm{~h}[33]$ & $32.6 \pm 6.5$ d [34] & 3.3 years [22] \\
\hline & M & $5.63 \pm 1.2 d[33]$ & $20.9 \pm 10.2$ d [34] & 3.8 years [22] \\
\hline \multirow[t]{2}{*}{ PFHA $\left(\mathrm{C}_{6} \mathrm{~F}_{13} \mathrm{COOH}\right)$} & $\mathrm{F}$ & $1.2 \mathrm{~h} \mathrm{[33]}$ & - & $70 \mathrm{~d}[35]$ \\
\hline & M & $2.4 \mathrm{~h} \mathrm{[33]}$ & - & \\
\hline \multirow[t]{2}{*}{$\mathrm{PFH} \times \mathrm{A}\left(\mathrm{C}_{5} \mathrm{~F}_{11} \mathrm{COOH}\right)$} & $\mathrm{F}$ & $0.4 \mathrm{~h} \mathrm{[36]}$ & $2.4 \pm 1.7 \mathrm{~h}[36]$ & - \\
\hline & M & $1 \mathrm{~h} \mathrm{[36]}$ & $5.3 \pm 2.5 \mathrm{~h}[36]$ & $32 \mathrm{~d}$ [37] \\
\hline \multirow[t]{2}{*}{$\mathrm{KPFBS}\left(\mathrm{C}_{4} \mathrm{~F}_{9} \mathrm{SO}_{3} \mathrm{~K}\right)$} & $\mathrm{F}$ & $4.51 \pm 2.22 \mathrm{~h}[38]$ & $95.2 \pm 27.1 \mathrm{~h}[38]$ & $45.7 \mathrm{~d}[38]$ \\
\hline & M & $3.96 \pm 0.21 \mathrm{~h}[38]$ & $83.2 \pm 41.9 \mathrm{~h} \mathrm{[38]}$ & $24.1 \mathrm{~d}[38]$ \\
\hline \multirow{2}{*}{$\begin{array}{l}\mathrm{GenX}\left(\mathrm{C}_{3} \mathrm{~F}_{7} \mathrm{OCF}\left(\mathrm{CF}_{3}\right)\right. \\
\left.\mathrm{COONH} \mathrm{H}_{4}\right)\end{array}$} & $\mathrm{F}$ & $<12 \mathrm{~h}[24]$ & - & - \\
\hline & M & $<12 \mathrm{~h}[24]$ & - & - \\
\hline $\mathrm{ADONA}\left(\mathrm{CF}_{3} \mathrm{OC}_{3} \mathrm{~F}_{6} \mathrm{O}\left(\mathrm{COONH}_{4}\right)\right.$ & M & $44 \mathrm{~h}[39]$ & - & $23.3 \pm 10.6$ d $[39]$ \\
\hline
\end{tabular}


Besides the hydro-fluorocarbon hybrid surfactant, another option is to introduce two short perfluorocarbon chains into a surfactant molecule to increase its hydrophobicity. For example, Shin's group $[49,50]$ synthesized two di-perfluorobutyl substituted sodium alkanesulfonate derivatives, and compared their surface activity with mono-perfluorobutyl derivatives (Scheme 1). The results showed that the compound 3 exhibited the highest surface activity with $\gamma_{\mathrm{CMC}}$ of $22.2 \mathrm{mN} / \mathrm{m}$ at CMC of 3.2 $\mathrm{mmol} / \mathrm{L}$, which might be ascribed to the more appropriate structure of compound 3 bearing one hydrophilic sulfonates head and two hydrophobic perfluorobutyl tails. Consequently, in practice, the hydrophile-lipophile balance should be thoroughly considered when designing the structure of surfactants [51]. Moreover, these compounds could be moderately degraded at biodegradable points, such as ether links, hydrocarbon moieties, and were retained below $60 \%$ level at 28 days in biodegradability test.

Wang et al. [52] reported the synthesis of a fluorinated Gemini sulfoacid surfactants with two perfluorohexyl chains $\left(2 \mathrm{C}_{6}{ }^{\mathrm{F}} \mathrm{C}_{3}\right.$-Sul). Firsitly, 3-perfluorohexyl-1,2-epoxypropane reacted with hexamethylenediamine to produce the intermediate with two secondary amino groups, and then the intermediate reacted with 1,3-propanesultone to obtain $2 \mathrm{C}_{6}{ }^{\mathrm{F}} \mathrm{C}_{3}$-Sul. Generally, the hydrophobicity of Gemini surfactants is stronger than that of monomeric surfactants in hydrocarbon surfactants, so Gemini surfactants are easier to form micelles in the aqueous solution and pack densely at the air-water interface than monomeric surfactants, presenting lower CMCs and surface tensions [43]. Here, this situation also is applicable for $2 \mathrm{C}_{6}{ }^{\mathrm{F}} \mathrm{C}_{3}$-Sul, which showed a higher surface activity with $\gamma_{C M C}$ of $20.27 \mathrm{mN} / \mathrm{m}$ at $\mathrm{CMC}$ of $0.082 \mathrm{mmol} / \mathrm{L}$. In this case, the decrease of electrostatic repulsion among polar head groups was also conducive to the close packing of surfactant molecules at the air-water interface [53]. With addition of $\mathrm{NaCl}$, the electric double layer was compressed to decrease electrostatic repulsion among polar head groups of $2 \mathrm{C}_{6}{ }^{\mathrm{F}} \mathrm{C}_{3}$-Sul, resulting in further decreasing $\mathrm{CMC}$ and $\gamma_{\mathrm{CMC}}(0.052 \mathrm{mmol}$ and 17.17 $\mathrm{mN} / \mathrm{m}, 50 \mathrm{mmol} / \mathrm{mL} \mathrm{NaCl}$ ). Furthermore, Wang's group [54] also investigated the effects of $\mathrm{pH}$ and inorganic salts on the surface activity of sodium salt of $2 \mathrm{C}_{6}{ }^{\mathrm{F}} \mathrm{C}_{3}$-Sul. The results showed that the surface activity increased in alkali $\mathrm{pH}$ range and in inorganic salts solutions. Compared with $\mathrm{NaCl}, \mathrm{CaCl}_{2}$ was more effective for the formation of micelles because the divalent $\mathrm{Ca}^{2+}$ bound more closely with the surfactant. The above results suggest that the surface activity of fluorinated surfactants can be improved in alkali $\mathrm{pH}$ range or adding inorganic salts, which might be an important way to save costs. Of course, it depends on the conditions of use.

Quagliotto et al. [55] also reported a series of Gemini fluorinated pyridinium surfactants with two perfluorohexyl chains $\left(\left[\mathrm{C}_{6} \mathrm{~F}_{13} \mathrm{CH}_{2} \mathrm{CH}_{2}\right.\right.$ py- $\left(\mathrm{CH}_{2}\right)_{\mathrm{n}}-\mathrm{pyCH}_{2}$ $\left.\mathrm{CH}_{2} \mathrm{C}_{6} \mathrm{~F}_{13}\right][\mathrm{Cl}]_{2}, n=3,4,8$ or 12, FGPn), and investigated the effects of spacer length on the surface activity of FGPn. With the increase of spacer length, the $\gamma_{\mathrm{CMC}}$ of FGPn increased from 27.7 (FGP3) to $30.9 \mathrm{mN} / \mathrm{m}$ (FGP12), but the change trend of $\mathrm{CMC}$ was atypical, which was due to the fact that fluorinated chains are not compatible with the hydrocarbon spacer to prevent the spacer from folding towards the fluorinated chain and further to prevent perfluorocarbon chains from packing closely at the air-water interface [56]. This result is similar to that of some<smiles>[R7]CCCC(CCC[R])(CCC[R])C(=O)OCC</smiles> 
conventional hydrocarbon surfactants[57, 58], indicating that a suitable spacer is meaningful to obtain a better surface activity effect in the design of surfactants. Furthermore, owing to the electrostatic interaction between the multiple cationic charges of FGPn and the negative charges of DNA phosphate groups, FGPn also were applied in the investigation of gene delivery $[9,59]$.

Shen et al. [60] also synthesized a series of special molecular structure nonionic short fluorocarbon chain surfactants $\left(\mathrm{F}_{\mathrm{m}} E \mathrm{G}_{\mathrm{n}} \mathrm{F}_{\mathrm{m}}\right)$ by connecting two short fluorocarbon chains $\left(\mathrm{C}_{\mathrm{x}} \mathrm{F}_{2 \mathrm{x}+1}, \mathrm{x}=6,4\right.$ or 2$)$ to the ends of polyethylene glycol (PEG, Mn=600 or $800 \mathrm{~g} / \mathrm{mol}$ ) with two isophorone diisocyanate units acted as spacers. Compared with other some non-bioaccumulable fluorinated surfactants $[40,41,45,61]$, the synthesis process of $F_{m} E G_{n} F_{m}$ was simpler to some extent due to a facile two-step coupling one-pot method, and no organic solvent was used. $\mathrm{F}_{13} \mathrm{EG}_{13} \mathrm{~F}_{13}$, which contains two longer hydrophobic chains $\left(\mathrm{CF}_{3}\left(\mathrm{CF}_{2}\right)_{5^{-}}\right)$and a shorter PFG chain $(\mathrm{Mn}=600 \mathrm{~g} / \mathrm{mol})$, showed the highest surface activity in the synthesized surfactants, whose $\gamma_{\mathrm{CMC}}$ was 17.8 $\mathrm{mN} / \mathrm{m}$ with a low $\mathrm{CMC}$ of $0.17 \mathrm{mmol} / \mathrm{L}$. Based on the special molecular structure, $\mathrm{F}_{13} \mathrm{EG}_{13} \mathrm{~F}_{13}$ with two fluorocarbon chains can occupied more area than PFOA with a single fluorocarbon chain at the air-water interface (as seen in Fig. 2), resulting in a CMC of about 100 times lower. Apart from a high surface activity, $\mathrm{F}_{13} \mathrm{EG}_{13} \mathrm{~F}_{13}$ showed excellent emulsifying ability and wettability, and simultaneously presented desirable salt and $\mathrm{pH}$ tolerance because the nonionic hydrophilic PEG chain is not easy to be affected by electrolytes. Furthermore, the cell cytotoxicity tests proved that $\mathrm{F}_{13} \mathrm{EG}_{13} \mathrm{~F}_{13}$ has no significant cytotoxicity. Hence, $\mathrm{F}_{13} \mathrm{EG}_{13} \mathrm{~F}_{13}$ can be used as a potential and promising alternative to PFOA.

In fact, the structure design of non-bioaccumulable perfluorocarbon chain surfactants is considered not only from the perspective of hydrophobic fluorocarbon chains, but also from the perspective of hydrophilic groups. For example, the easily available and ecofriendly multiplehydroxyl natural products, including glucose, maltose, and inositol, have introduced into nonionic fluorinated surfactants to act as the hydrophilic moiety. The following is a brief introduction of some cases.

Bongartz et al. [62] synthesized a new fluorinated inositol-based surfactant containing two ethylene oxide units (as a spacer) and a $\mathrm{CF}_{3}\left(\mathrm{CF}_{2}\right)_{5^{-}}$, whose $\gamma_{\mathrm{CMC}}$ was $17.4 \mathrm{mN} / \mathrm{m}$ at $\mathrm{CMC}$ of $0.39 \mathrm{mmol} / \mathrm{L}$. Boussambe et al. [63] reported fluorinated diglucose surfactants $\left(\mathrm{F}_{n} \mathrm{H}_{2}\right.$ DigluM) with a short fluorocarbon chain $\left(C_{n} F_{2 n+1}, n=4\right.$ or 6). As the increase of perfluorocarbon chain length from 4 to $6, \mathrm{CMCs}$ of $\mathrm{F}_{\mathrm{n}} \mathrm{H}_{2}$-DigluM sharply decreased from 14.4 to $0.72 \mathrm{mmol} / \mathrm{L}$, while the ability to reduce surface tension did not increase and the $\gamma_{\mathrm{CMC}}$ of $\mathrm{F}_{4} \mathrm{H}_{2-}$ DigluM was smallest $(27.8 \mathrm{mN} / \mathrm{m})$ in $\mathrm{F}_{\mathrm{n}} \mathrm{H}_{2}$-DigluM, revealing once again that an appropriate hydrophobic chain length is very important to obtain a desired surface activity effect. Presently, this sort of fluorinated surfactants containing multiplehydroxyl natural product groups are mainly used in handling membrane proteins (see 3.2 section for details). Moreover, it is should be noted that the water solubility of the some surfactants bearing only one natural product hydrophilic unit is poor [64, 65]. The introduction of oxyethene fragments $\left(-\mathrm{OCH}_{2} \mathrm{CH}_{2}-\right)$ or the multiple natural product hydrophilic units into the hydrophilic moiety can improve the water solubility of the entire surfactant molecule.

\subsection{Surfactants with weak points on fluorocarbon chain}

The introduction of weak points into the fluorocarbon chain of surfactants, such as the methylene group and the ether bond, is deemed to facilitate fluorocarbon

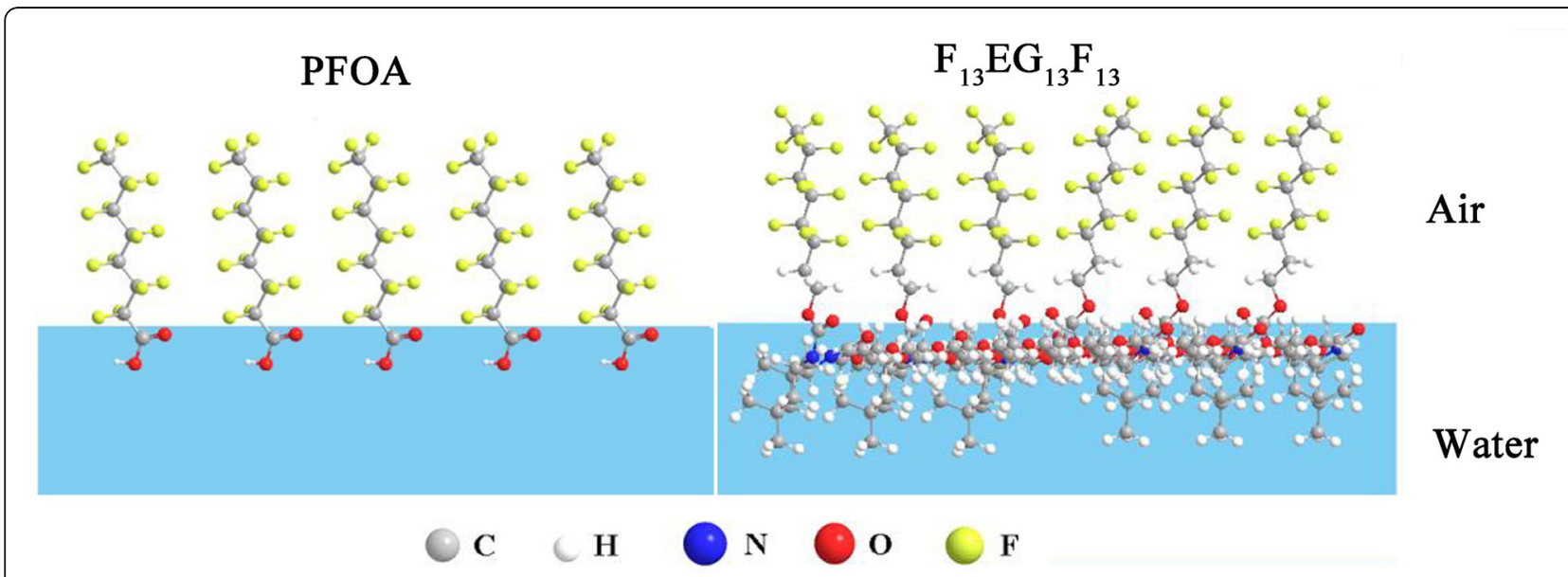

Fig. 2 Schematic representation of adsorption behavior for PFOA and $F_{13} E G_{13} F_{13}$ molecules at the air-water interface [60]. Copyright 2019, Elsevier 
chain degradation and realize non-bioaccumulation [9]. There are two most common reaction routes to inset weak points into the fluorocarbon chain [66], including the anionic ring opening oligomerization of hexafluoropropylene oxide to form the perfluoropolyether chain and the radical telomerization of non-perfluoro olefins such as vinylidene fluoride $\left(\mathrm{CH}_{2} \mathrm{CF}_{2}\right.$, VDF) and 3,3,3-trifluoropropene $\left(\mathrm{CF}_{3} \mathrm{CHCH}_{2}\right.$, TFP) to inset methylene groups or methine groups into the fluorocarbon chain.

Perfluoropolyetheracyl halide or carboxylic acid compounds, which are derived from the anionic ring opening oligomerization of hexafluoropropylene oxide, are common commercial intermediates for the synthesis of perfluoropolyether surfactants. Wang's group [67-69] reported three perfluoropolyether surfactants with different hydrophilic head groups (Scheme 2). Due to the high fluorine content, these perfluoropolyether surfactants exhibited high surface activity, with $\gamma_{\mathrm{CMC}}$ of $16-17 \mathrm{mN} / \mathrm{m}$. And their hydrophobic chain was formed by connecting shorter fluorocarbon units with multiple ether bonds which gave biodegradation and non-bioaccumulation to perfluoropolyether surfactants. At the same time, these surfactants also showed excellent wettability and could effectively reduce the contact angle on polytetrafluoroethylene (PTFE) and paraffin film, which are two typical low-energy hydrophobic surfaces.

In some special condition, surfactants with longer perfluoropolyether chains can better meet the application requirements. For example, compared with typically perfluorinated C8-based surfactants, surfactants with longer perfluoropolyether chains can achieve a sufficient longterm emulsion stability to water-in-fluorocarbon oil emulsions [70-72]. Wagner et al. [73] synthesized two triblock nonionic perfluoropolyether (40 repeating units) surfactants with the linear polyglycerol (LPG (OR)) as the hydrophilic group (as seen in Fig. 3a). The synthesis process is as follows: firstly, the poly (perfluoropropylene glycol) (PFPE) carboxylic acid was converted to the acid chloride using dichlorosulfoxide; then, the acid chloride reacted with corresponding linear polyglycerol diamine to yield the target surfactants with hydroxyl groups (LPG $(\mathrm{OH})-\mathrm{PFPE}_{2}$ ) or methyl groups (LPG (OMe)$\left.\mathrm{PFPE}_{2}\right)$. The interface tension between fluorinated oil (HFE7500, $3 \mathrm{M}$ ) and water was $18 \mathrm{mN} / \mathrm{m}$ at $\mathrm{CMC}$ of $0.02 \mathrm{wt} \% \mathrm{LPG}(\mathrm{OMe})-\mathrm{PFPE}_{2}$, and the water-in-oil emulsion microdroplet composed of deionized water, HFE7500, and LPG (OMe)-PFPE2 was very stable (as seen in Fig. 3b); LPG (OH)-PFPE 2 water-in-oil emulsion was unstable and the interface tension at CMC could not be measured accurately due to the uncontrolled aggregation of LPG $(\mathrm{OH})-\mathrm{PFPE}_{2}$ induced by its stronger hydrogen bonding. Hence, compared with PEG fluorinated surfactants, the performances of linear polyglycerol fluorinated surfactants can be adjusted not only by the molecular weight, but also by the side-chain modification [72]. In addition, the in vitro translation (IVT) experiment carried out in LPG (OMe)-PFPE2 water-in-oil emulsion droplets proved that the surfactant has excellent biocompatibility and can be used in biological analysis.

In the synthesis of fluorinated surfactants, the radical telomerization is an important method to control the extension of the fluorocarbon chain length. When using the non-perfluoro olefin as the telomeric monomer, the biodegradable and non-bioaccumulable fluorinated surfactant can be obtained. Boutevin et al. [74] prepared two anionic fluorinated surfactants with a carboxylate $\left(\mathrm{C}_{\mathrm{n}} \mathrm{F}_{2 \mathrm{n}+1}\left(\mathrm{CH}_{2} \mathrm{CF}_{2}\right)_{2} \mathrm{CH}_{2} \mathrm{COOH}, \quad n=2\right.$ and $4, \quad$ and

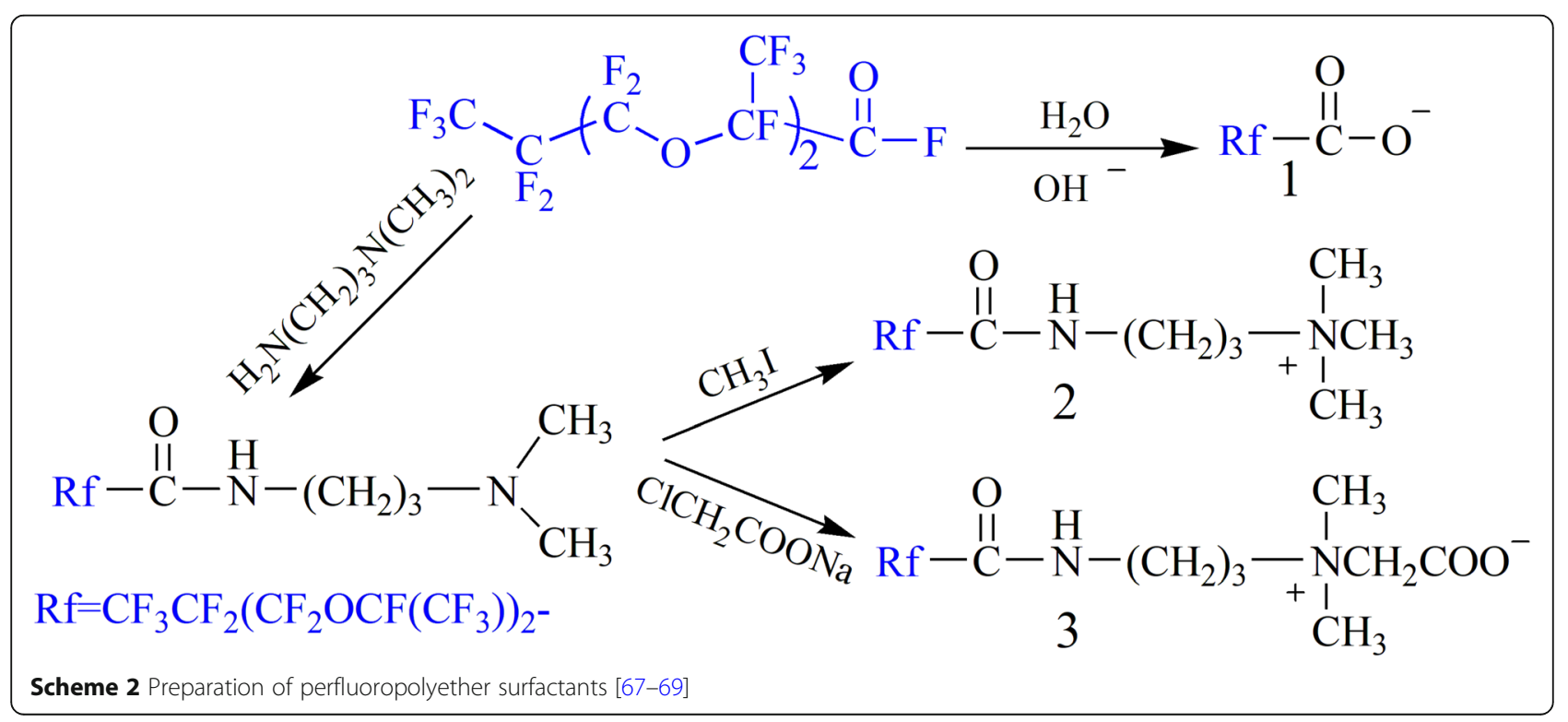


(a)

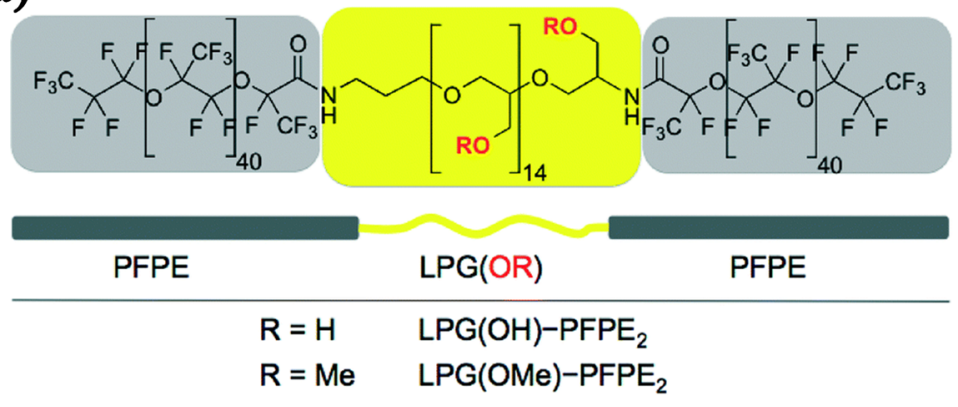

(b)

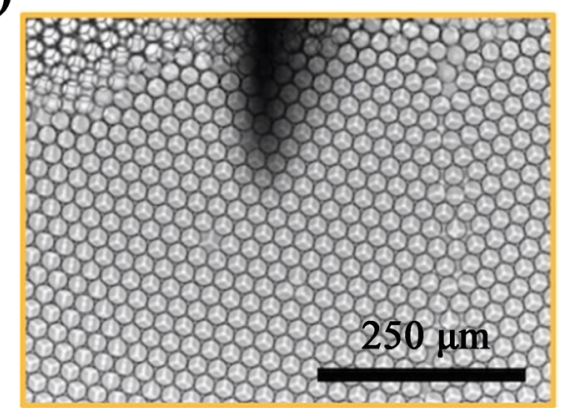

Fig. 3 Chemical structure of LPG $(\mathrm{OH})$ and LPG (OMe) (a); W/O microemulsion stabilized with LPG (OMe)-PFPE2 that remained stable when mechanical stress was applied (b) [73]. Copyright 2016, Royal Society of Chemistry

abbreviated as F-surf 2-2 and F-surf 4-2, respectively) using the radical telomerization of VDF with 1iodoperfluoroalkane [75-77] (Scheme 3). In order to control the chain length of fluorotelomeres and obtain suitable low molecular weight fluorotelomeres, the experimental conditions (solvents, initiators and temperature) were also investigated in detail. The $\gamma_{\mathrm{CMC}}$ for F-surf 2-2, whose carbon chain length is same with that of PFOA, was $19.8 \mathrm{mN} / \mathrm{m}$ at $5 \mathrm{~g} / \mathrm{L}$ (about 3.5 times of $\mathrm{CMC}$ ). This method based on the radical telomerization of VDF provides weak sites in the hydrophobic chain, such as methylenes whose $\mathrm{C}-\mathrm{H}$ bonds is weaker compared to C-F [78], and is valuable for the development of novel fluorinated surfactants with degradable ability.

Yake et al. [79] reported two kind of fluorinated cationic surfactants with pyridinium sulfonates or ammonium hydrochlorides, whose fluoroalkyl chain was interrupted by the ether bond or methylene. Here, some representative examples are selected (as seen in Table 3). VDF and TFE (trafluoroethylene) units were inserted into the surfactant molecules to extend fluorocarbon chain length and improve the ability of reducing surface tension, and the ether bond or methylene in surfactants provided degradable sites. Compared with compound II-B, compound III-B with an isopropylidene group as a spacer had a lower efficiency to reduce the surface tension because the isopropylidene group could interrupt the tight packing of molecules on the air-water interface and disrupt the hydrophilic-lipophilic balance of the surfactant [80]. Furthermore, both III-A and II-B showed an excellent foaming ability and stability in the simulative foam drilling fluid condition $(2 \% \mathrm{KCl}$ and $15 \% \mathrm{HCl}$ aqueous solutions).

\subsection{Surfactants with branched fluorocarbon chain}

In the reported literatures [81-83], the branched fluorinated surfactants denote the surfactants containing multiple fluorinated side groups like $\mathrm{CF}_{3-}$ and $\left(\mathrm{CF}_{3}\right)_{2} \mathrm{CF}-$ on the fluorocarbon main chain. These branched fluorinated surfactants are based on hexafluoropropylene oligomer such as hexafluoropropene dimer and hexafluoropropene trimer, whose length of fluorinated main chains are shorter than or equal to C6.

Jiang's group [84-88] prepared several branched fluorinated surfactants bearing a branched $\mathrm{CF}_{3} \mathrm{CF}_{2} \mathrm{CF}_{2} \mathrm{C}\left(\mathrm{CF}_{3}\right)_{2}$ group using hexafluoropropene dimer as a starting material (Scheme 4). The surface tension of the synthesized branched fluorinated surfactants can be effectively reduced to around $20 \mathrm{mN} / \mathrm{m}$. It should be pointed out that the $\mathrm{CMC}$ of sample 1 with only a $\mathrm{CF}_{3} \mathrm{CF}_{2} \mathrm{CF}_{2} \mathrm{C}\left(\mathrm{CF}_{3}\right)_{2}$ group is relatively higher, indicating that a larger dosage is needed to obtain a better effect in practice. When a hydrophobic chain or a rigid spacer was introduced into the branched fluorinated surfactants based on sample 1, CMCs of the prepared surfactants sharply decreased. For example, the CMC of sample 1 was $1.41 \times 10^{-2} \mathrm{~mol} / \mathrm{L}$,

$$
\begin{aligned}
& \left.\mathrm{C}_{\mathrm{n}} \mathrm{F}_{2 \mathrm{n}+1} \mathrm{I}+{ }_{\mathrm{m}}^{\mathrm{H}} \mathrm{C}_{2}=\mathrm{CF}_{2} \stackrel{\text { Rad. }}{\longrightarrow} \mathrm{Rf}+\stackrel{\mathrm{H}_{2}}{\mathrm{C}}-\stackrel{\mathrm{F}_{2}}{\mathrm{C}} \underset{\mathrm{m}_{\mathrm{m}}}{\mathrm{I}} \frac{\text { 1) }{ }_{\text {2) } \mathrm{DMF}_{2} \mathrm{H}}^{\mathrm{C}}=\mathrm{CH}_{2}}{\longrightarrow} \mathrm{Rf}+\stackrel{\mathrm{H}_{2}}{\mathrm{C}}-\stackrel{\mathrm{F}_{2}}{\mathrm{C}}\right)_{\mathrm{m}} \stackrel{\mathrm{H}_{2}}{\mathrm{C}}-\mathrm{COOH} \\
& \mathrm{Rf}=\mathrm{C}_{\mathrm{n}} \mathrm{F}_{2 \mathrm{n}+1}, \mathrm{n}=2,4 \\
& \text { 3) } \mathrm{H}_{2} \mathrm{SO}_{4} / \mathrm{Cr}_{2} \mathrm{O}_{3}
\end{aligned}
$$

Scheme 3 The radical telomerization of VDF with $C_{n} F_{2 n+1}$ to synthesize fluorinated surfactants [74] 
Table 3 Surface tensions ( $\mathrm{mN} / \mathrm{m}$ ) of fluorinated pyridinium and ammonium cationic surfactants in deionized water at $23^{\circ} \mathrm{C}$ [79]

\begin{tabular}{|c|c|c|}
\hline \multirow[t]{2}{*}{ Surfactants } & \multicolumn{2}{|c|}{ Concertration (wt\%) } \\
\hline & 0.1 & 0.5 \\
\hline$\left[\mathrm{C}_{4} \mathrm{~F}_{9} \mathrm{CH}_{2} \mathrm{CF}_{2} \mathrm{CH}_{2} \mathrm{CH}_{2}\right.$ py] $\left[\mathrm{p}-\mathrm{CH}_{3} \mathrm{C}_{6} \mathrm{H}_{4} \mathrm{SO}_{3}\right](\mathrm{I}-\mathrm{A})$ & 43.1 & 22.8 \\
\hline$\left[\mathrm{C}_{4} \mathrm{~F}_{9}\left(\mathrm{CH}_{2} \mathrm{CF}_{2}\right)_{2} \mathrm{CH}_{2} \mathrm{CH}_{2} \mathrm{py}\right]\left[\mathrm{p}-\mathrm{CH}_{3} \mathrm{C}_{6} \mathrm{H}_{4} \mathrm{SO}_{3}\right](\mathrm{II}-\mathrm{A})$ & 30.5 & 19.5 \\
\hline$\left[\mathrm{C}_{6} \mathrm{~F}_{13}\left(\mathrm{CH}_{2} \mathrm{CF}_{2}\right)_{2} \mathrm{CH}_{2} \mathrm{CH}_{2} \mathrm{py}\right]\left[\mathrm{p}-\mathrm{CH}_{3} \mathrm{C}_{6} \mathrm{H}_{4} \mathrm{SO}_{3}\right](\mathrm{III}-\mathrm{A})$ & 18.8 & 18.3 \\
\hline$\left[\mathrm{C}_{8} \mathrm{~F}_{17} \mathrm{CH}_{2} \mathrm{CH}_{2} \mathrm{py}\right]\left[\mathrm{p}-\mathrm{CH}_{3} \mathrm{C}_{6} \mathrm{H}_{4} \mathrm{SO}_{3}\right]^{\mathrm{a}}$ & 17.2 & 17.0 \\
\hline$\left[\mathrm{C}_{3} \mathrm{~F}_{7} \mathrm{O}\left(\mathrm{CF}_{2} \mathrm{CF}_{2}\right)_{2} \mathrm{CH}_{2} \mathrm{CH}_{2} \mathrm{NH}_{3}\right][\mathrm{Cl}](\mathrm{I}-\mathrm{B})$ & 25.8 & 14.3 \\
\hline$\left[\mathrm{C}_{3} \mathrm{~F}_{7} \mathrm{O}\left(\mathrm{CF}_{2} \mathrm{CF}_{2}\right)_{3} \mathrm{CH}_{2} \mathrm{CH}_{2} \mathrm{NH}_{3}\right][\mathrm{Cl}](\mathrm{II}-\mathrm{B})$ & 16.4 & 14.8 \\
\hline$\left[\mathrm{C}_{3} \mathrm{~F}_{7} \mathrm{O}\left(\mathrm{CF}_{2} \mathrm{CF}_{2}\right)_{3} \mathrm{C}\left(\mathrm{CH}_{3}\right)_{2} \mathrm{NH}_{3}\right][\mathrm{Cl}](\mathrm{III}-\mathrm{B})$ & 54.7 & 28 \\
\hline$\left.\left[\mathrm{RfCH}_{2} \mathrm{CH}_{2} \mathrm{NH}_{3}\right][\mathrm{Cl}]\right]^{b}$ & 23.7 & 20.9 \\
\hline
\end{tabular}

${ }^{a}$ the reference of fluorinated pyridinium cationic surfactants

${ }^{\mathrm{b}}$ the reference of fluorinated ammonium cationic surfactants (where $\mathrm{Rf}$ is the mixture of $\mathrm{C}_{8} \mathrm{~F}_{17}$ and $\mathrm{C}_{10} \mathrm{~F}_{21}$ (molar ratio of $45: 55$ )) while the $\mathrm{CMCs}$ of sample $4 \mathrm{~d}$ with two branched $\mathrm{CF}_{3} \mathrm{CF}_{2} \mathrm{CF}_{2} \mathrm{C}\left(\mathrm{CF}_{3}\right)_{2}$ - group and sample 3 containing a rigid benzene ring were $1.74 \times 10^{-6}$ and $1.04 \times 10^{-4} \mathrm{~mol} / \mathrm{L}$, respectively. Once again, the results proved that the introduction of an appropriate hydrophobic structure into the surfactant is beneficial to the formation of micelles and the decrease of CMC.

Wei et al. [89] synthesized a branched fluorinated surfactant (BFIS, as seen in Fig. 4a), which derived from hexafluoropropene trimer and 4-hydroxybenzyl alcohol, and compared its surface activity with a straight chain surfactant (SFIS, as seen in Fig. 4b). Owing to the existence of rigid benzene ring and imidazole ring spacers, CMCs of BFIS and SFIS were lower but not distinctly different, with 0.122 and $0.181 \mathrm{mmol} / \mathrm{L}$, respectively. And the surface tension could be effectively reduced to $18.66 \mathrm{mN} / \mathrm{m}$ for BFIS and $18.48 \mathrm{mN} / \mathrm{m}$ for SFIS,

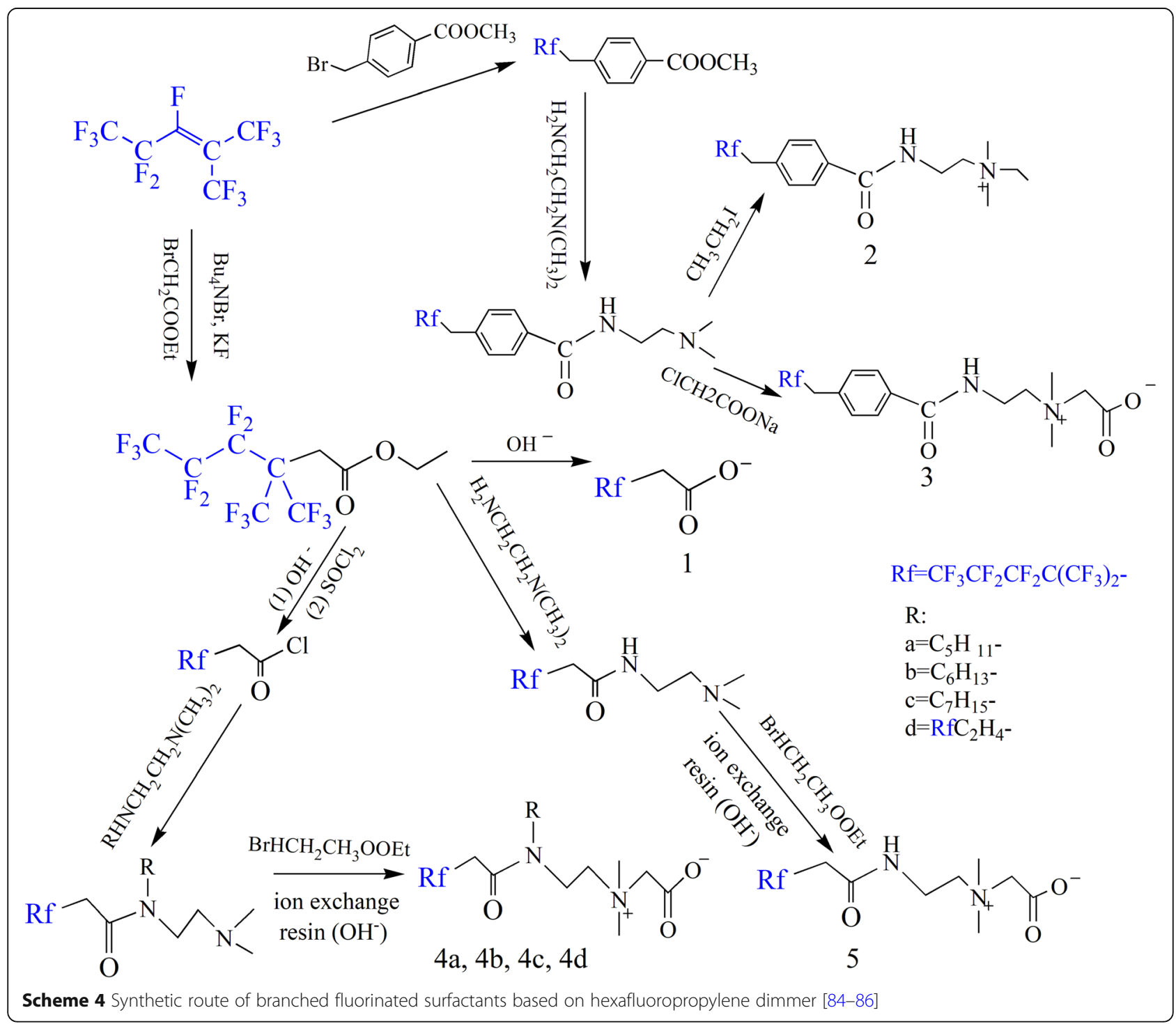


respectively, at $5 \mathrm{mmol} / \mathrm{L}$. Since the packed adsorption layer of BFIS was denser than that of SFIS on the metal surface, BFIS showed better anticorrosion performance, indicating that the branched fluorinated surfactant can be used as a promising metal corrosion inhibitor. The adsorption behavior at the air-solid interface and metal corrosion inhibition mechanism of BFIS and SFIS is shown in Fig. 4c.

\section{Application of non-bioaccumulable fluorinated surfactants}

Because of their excellent performances, the fluorinated surfactants sometimes play an important and special role which cannot be replaced by common hydrocarbon surfactants in practical applications. The nonbioaccumulable fluorinated surfactants, serving as the alternatives of conventional fluorinated surfactants with long fluorocarbon chain, now have been used in emulsion polymerization of fluorinated olefins, membrane proteins treatment, leather manufacture and other fields, which meet not only environmental requirements but also requirements for use.

\subsection{Application in emulsion polymerization of fluorinated olefins}

Since the miscibility between fluorinated monomers with conventional hydrocarbon surfactants is poor, fluorinated surfactants are usually selected as an emulsifier in the emulsion polymerization of fluoropolymers according to the principle of "like dissolves like" [90]. For example, APFO and NaPFO are acted as emulsifiers in the emulsion polymerization of PTFE, perfluorinated ethylene-propylene copolymer (FEP), and perfluoroalkoxy polymer (PFA) [24]; and APFO is used as an emulsifier in the emulsion polymerization of polyvinylidene fluoride (PVDF) [91, 92].

Now non-bioaccumulable fluorinated surfactants have been used as emulsifiers in the emulsion polymerization of fluorinated olefins. For instance, Banerjee et al. [93] prepared a PVDF emulsion using a degradable fluorinated surfactant 3-hydroxy-2-(trifluoromethyl) propanoic acid (MAF-OH) as an emulsifier (as seen in Fig. 5). Average particle diameter of the prepared PVDF latex particles decreased with the increase of MAF-OH concentration, about $100 \mathrm{~nm}$ at $2.0 \mathrm{wt} \% \mathrm{MAF}-\mathrm{OH}$, and the prepared PVDF latex particles were perfectly spherical. Kang et al. [47] also prepared a PVDF emulsion using the synthesized non-bioaccumulable hybrid surfactant $\mathrm{F}_{2} \mathrm{H}_{8}$ (see section 2.1) as an emulsifier. Compared with a

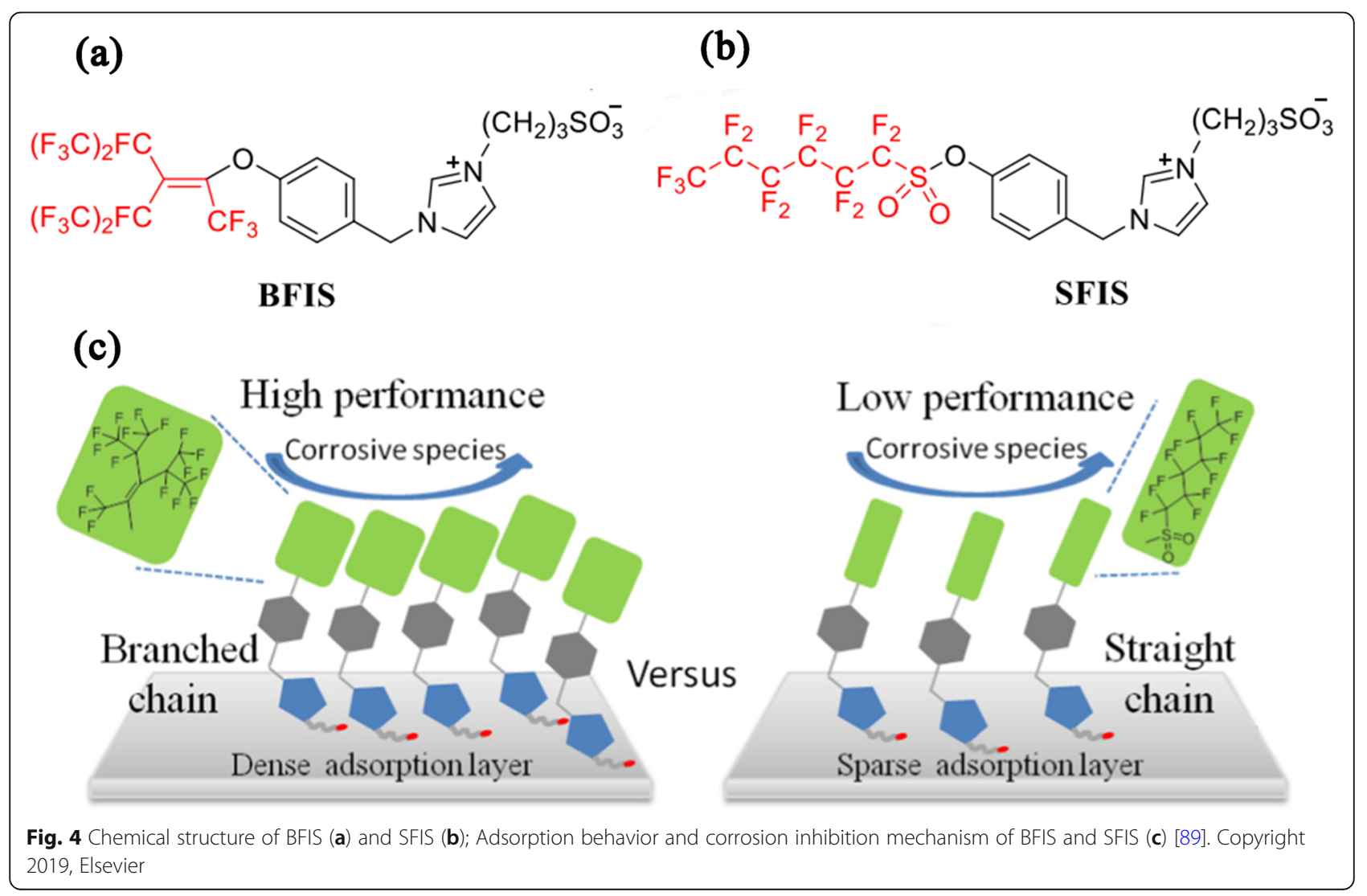




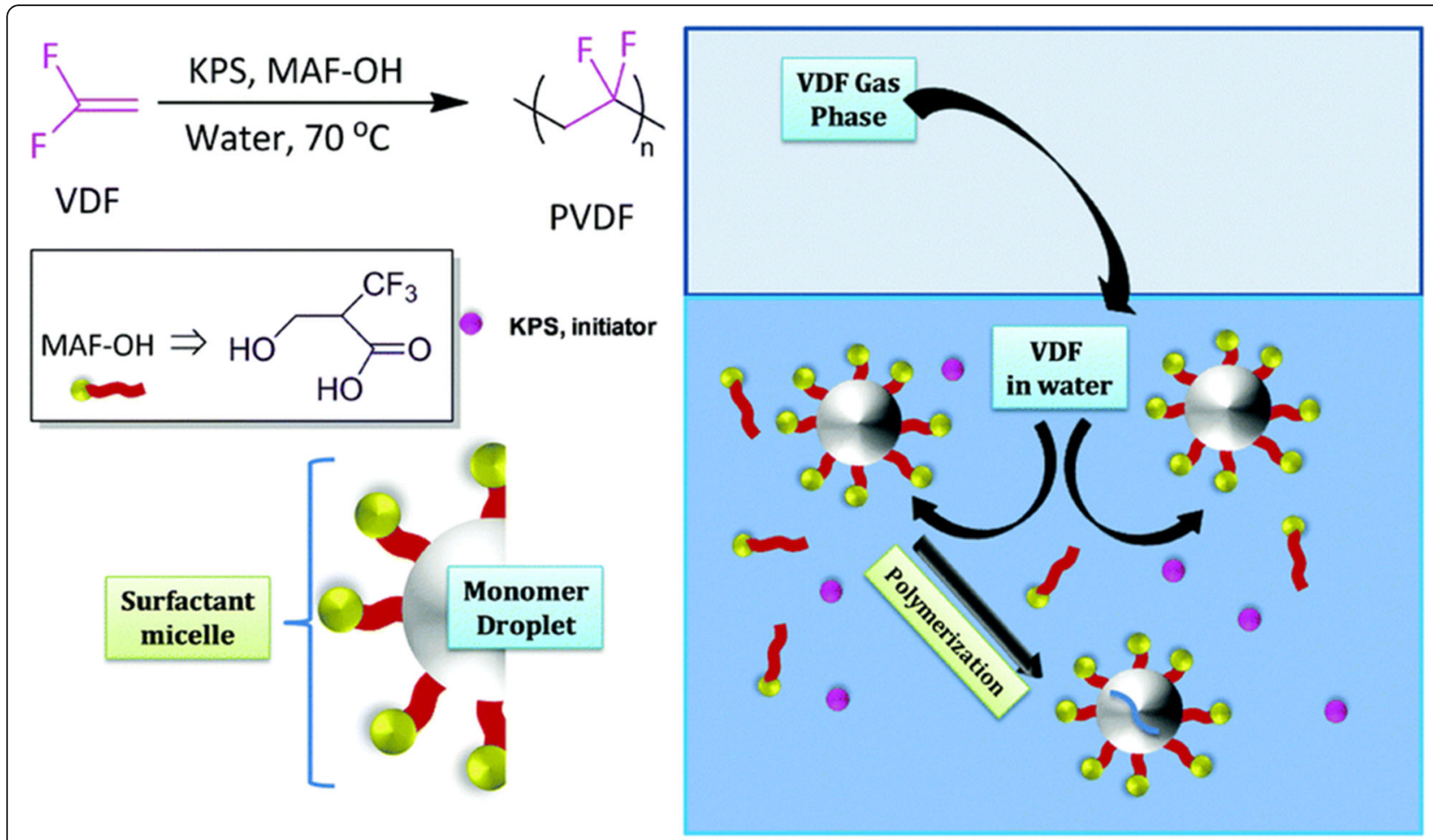

Fig. 5 Emulsion polymerization of VDF [93]. Copyright 2018, Royal Society of Chemistry

PVDF emulsion with APFO under same conditions, their effects (i.e., $\mathrm{F}_{2} \mathrm{H}_{8}$ and APFO) were almost the same, with the solid content of 22 and $23 \mathrm{wt} \%$ and average diameters of 257.4 and $242.7 \mathrm{~nm}$, respectively. Scanning electron microscope (SEM) images of PVDF particles are shown in Fig. 6.

In order to avoid the disadvantages of desorption or migration of conventional fluorinated surfactants from the polymer, polymerizable fluorinated surfactants are also generated and applied. Zhao et al. [94] synthesized a polymerizable non-bioaccumulable fluorinated surfactant perfluoro (4-methyl-3,6-dioxaoct-7-ene) sodium sulfonate (PSVNa), which could reduce the surface tension of its aqueous solution to a minimum of $26 \mathrm{mN} / \mathrm{m}$ at $4.0 \mathrm{wt} \%$. Using PSVNa, PSVNa/sodium dodecyl sulfate (SDS) binary mixtures and PFOA as emulsifiers, the effects of different emulsifiers on latex particles of DFHM A/MMA copolymer were studied. The results showed that the gel content of emulsion with only PSVNa was lowest $(0.6 \mathrm{wt} \%)$. Meanwhile, since PSVNa has a double bond, PSVNa can be covalently linked to the polymer chain during the emulsion polymerization, remaining the stability of the emulsion. Emulsions with PSVNa or PSVNa/SDS were very stable and could be stored for at least 3 years at the ambient temperature, far exceeding PFOA (a half year).
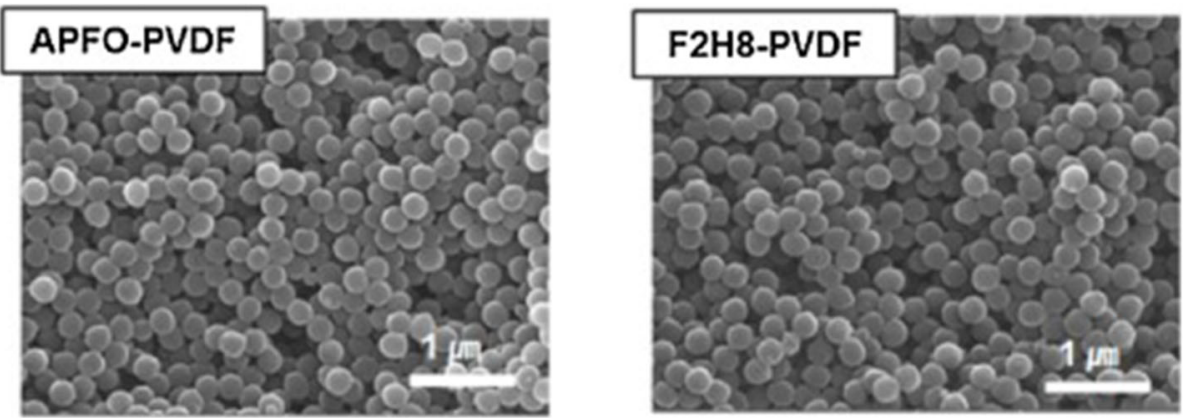

Fig. 6 SEM images of the PVDF particles obtained using APFO and $\mathrm{F}_{2} \mathrm{H}_{8}$ as surfactants [47]. Copyright 2018, Elsevier 


\subsection{Application in handling membrane proteins}

In the treatment of membrane proteins including extraction, purification and structural characterization, fluorinated surfactants are usually used as a solubilizer to solubilize biological membranes. Compared with hydrocarbon surfactants, the fluorocarbon chain of fluorinated surfactants is bulkier and more rigid, and the affinity between hydrogenated surfaces of membrane proteins and fluorinated surfactants is little, so they are less likely to intrude into the protein structure, avoiding inactivation of membrane proteins [95].

Since they are used for handling membrane proteins, fluorinated surfactants have achieved encouraging results in stability of membrane protein [96]. Presently, the most commonly used fluorinated surfactants for membrane protein studies are fluoroalkyl glycosides such as the maltoside and glucoside series because of their mildness [97-99]. And they are mostly fluorinated surfactants based on $\mathrm{C} 4$ or C6 fluorocarbon chain. For example, Durand'group [100] found that F6-Diglu, where "F6" denotes six fluorinated carbons of the hydrophobic tail and "Diglu" represents two glucose moieties, could self-assemble into small and homogeneous globular micelles $(5-6 \mathrm{~nm})$ which can stabilize membrane proteins. Subsequently, the research group reported several fluorinated surfactants based on F6-Diglu and their application in handling membrane proteins [101, 102], which could self-assembled into small aggregates in the aqueous solution, about $5-11 \mathrm{~nm}$. In the stabilization experiments of the model membrane protein bacteriorhodopsin, fluorinated surfactants /membrane protein bacteriorhodopsin heterogeneous complexes could be stabled for 3 months. In addition, this group [63] also extracted proteins from native Escherichia colimembranes using the synthesized fluorinated surfactants $\mathrm{F}_{\mathrm{n}} \mathrm{H}_{2}$-DigluM ( $n=4$ or 6 , see 2.1 section). The results showed that $\mathrm{F}_{4} \mathrm{H}_{2}$-DigluM could essentially complete the solubilization of membrane proteins after $15 \mathrm{~h}$, and $\mathrm{F}_{4} \mathrm{H}_{2}$-DigluM presented a good membrane protein extracting efficiency, which was similar with DDM (ndodecyl- $\beta$-D-maltopyranoside, a commonly used detergent in membrane proteins extraction) at $1-2 \mathrm{mmol} / \mathrm{L}$ above the respective $\mathrm{CMC}$, about $5 \%$.

Similarly, maltose-based non-bioaccumulable fluorinated surfactants were also applied in handling membrane proteins. For example, Polidori et al. [103] synthesized two new maltose-based fluorinated surfactants $\left(\mathrm{F}_{2} \mathrm{H}_{9} \beta \mathrm{M}\right.$ and $\left.\mathrm{F}_{4} \mathrm{H}_{5} \mathrm{\beta M}\right)$ containing either a $\mathrm{CF}_{3} \mathrm{CF}_{2}\left(\mathrm{CH}_{2}\right)_{9^{-}}$or a $\mathrm{CF}_{3}\left(\mathrm{CF}_{2}\right)_{3}\left(\mathrm{CH}_{2}\right)_{5^{-}}$at the end of the hydrophobic chain. The $\gamma_{\mathrm{CMC}}$ values of $\mathrm{F}_{2} \mathrm{H}_{9} \beta \mathrm{M}$ and $\mathrm{F}_{4} \mathrm{H}_{5} \beta \mathrm{M}$ were 26 and $22 \mathrm{mN} / \mathrm{m}$, respectively, and their CMC values were 1.14 and $2.16 \mathrm{mmol} / \mathrm{L}$, respectively. In the stabilization test, the model membrane protein bacteriorhodopsin was stable over approximately a month in $F_{2} \mathrm{H}_{9} \beta M$ but for more than a year in $\mathrm{F}_{4} \mathrm{H}_{5} \beta \mathrm{M}$, and the effect of $\mathrm{F}_{4} \mathrm{H}_{5} \beta \mathrm{M}$ was almost the same as that of commercial fluorinated octyl maltoside $\left(\mathrm{F}_{6} \mathrm{H}_{2} \beta \mathrm{M}\right)$ [104].

\subsection{Application in leather manufacture}

Owing to their excellent performances, fluorinated surfactants can be applied in leather manufacture to impart leather some special properties and further improve significantly the quality of leather. After the conventional perfluorooctyl surfactant products such as $3 \mathrm{M}$ Scotchguard $^{\text {tix }}$ FC-805 (a typical finishing agent based on PFOA) [105] are banned, non-bioaccumulable fluorinated surfactants have been used in leather manufacture.

In the wet finishing process of leather manufacture, fluorinated surfactants acting as the auxiliary can promote permeation, absorption or diffusion of other leather chemicals in leather fiber to achieve a desired process effect and further improve the use value and economic value of leather. The U.S. patent [106] reported a kind of non-bioaccumulable perfluoropolyether surfactant, which can be used as the dye dispersant. And Sagisaka et al. [107] proved that the sulfonate fluorinated surfactants bearing double $-\left(\mathrm{CF}_{2}\right)_{4} \mathrm{~F}$ groups (with $\gamma_{\mathrm{CMC}}$ $18 \mathrm{mN} / \mathrm{m}$ at $0.26 \mathrm{mmol} / \mathrm{L}$ ) could quickly dissolve a hydrophilic dye methyl orange into water/supercritical $\mathrm{CO}_{2}$ microemulsions in just a few seconds. Of course, in the processing process, fluorinated surfactants also will be adsorbed or bound on the fiber surface of leather to make its surface tension lower than that of water, playing a role of water repellent for leather. Our group[108] used the synthesized nonionic short-chain fluorinated surfactants (Fm-Fm, m represents the length of fluorocarbon chain, see 2.1 section [60]) as fatliquoring auxiliaries in the fatliquoring process of chrome-tanned goat skin to investigate the effect of type and dosage of surfactants as well as fatliquoring temperature on fatliquoring properties. The results showed that at $40{ }^{\circ} \mathrm{C}$, $1 \mathrm{wt} \%$ F4-F4 with two perfluorobutyl groups exhibited significant effect on improving softness and physical mechanical properties of the resultant leather. And compared with leather treated without fluorinated surfactants (contact angle of $82^{\circ}$ ), the maximum contact angle of the leather treated with F6-F6 was $110^{\circ}$, enhancing waterproofness of leather.

In the dry finishing process of leather manufacture, the fluorinated surfactants can be used as the water- and oil-repellent finishing agent of leather, whose fluorinated moieties provide a water and oil resistance and hydrophilic moieties (such as hydroxy groups, carboxyl groups and oxyethene fragments) realize the easy washing and decontamination of the resultant leather. At present, the most popular water-and oil-repellent leather finishing agents are the non-bioaccumulable fluorinated acrylates copolymer, and the Capstone ${ }^{\mathrm{Tw}}$ LPA based on the short 
C4 fluorocarbon chain (Chemours Company)(www. chempoint.com/products/chemours/capstone-

fluorosurfactants/capstone-repellents-for-leather) is one of the most representative commercial products. These kinds of leather finishing agents are also reported on some patents $[109,110]$. Due to the possible commercial interests, their detailed formulas are mostly unclear. And only few articles publicly report their details. For instance, Liu et al. [111] reported a non-bioaccumulable water-repellent leather finishing agent. Firstly, the macromolecule fluorinated surfactant was prepared (FSAa) using $1 \mathrm{H}, 1 \mathrm{H}, 7 \mathrm{H}$-dodecafluoroheptyl methacrylate $\left(\mathrm{R}_{\mathrm{f}} \mathrm{AA}, \mathrm{R}_{\mathrm{f}}=\mathrm{CHF}_{2}\left(\mathrm{CF}_{2}\right)_{5^{-}}\right)$, acrylic acid (AA) and hydroxypropyl acrylate (HPAA) (molar ratio, 1:2:1) as monomers. Then, the $\mathrm{R}_{\mathrm{f}} \mathrm{AA} / \mathrm{SMA} / \mathrm{HPAA}$ emulsion $(\mathrm{FSH})$ was successfully prepared by emulsier-free polymerization with $\mathrm{R}_{\mathrm{f}} \mathrm{AA}$, stearyl methylacrylate (SMA), and HPAA (80 wt\%:16.5 $\mathrm{wt} \%: 3.5 \mathrm{wt} \%$ ) as monomers and F-SAa as an emulsifier. Average size $(109.9 \mathrm{~nm})$ and its distribution range (polydispersity index of 0.326 ) of the prepared FSH latex particles were smaller, which contributed FSH to permeate and spread in the leather fiber. The goat wet blue skin treated with FSH showed an excellent water-repellent effect due to the higher fluorine content of F-SAa, with the contact angle of $137.6^{\circ}$.

\section{Conclusion and outlook}

So far, non-bioaccumulable fluorinated surfactants have made tremendous progress in its preparation and application. In this review, many listed non-bioaccumulable fluorinated surfactants with different fluorocarbon chain structures including the short perfluorocarbon chain, the fluorocarbon chain with weak points, and the branched fluorocarbon chain, present excellent performances, which is comparable to PFOA. And their performances can be further adjusted by the length of spacers, the type of counter ions and other factors. We summarize these structure-activity relationships with expect to provide meaningful references for the development of nonbioaccumulable fluorinated surfactants with a higher surface activity. At the same time, in some application fields listed in this article, non-bioaccumulable fluorinated surfactants also exhibit better practical application effects, which take into account environmental protection and usability.

Of course, the current challenges faced by nonbioaccumulable fluorinated surfactants have to be considered. On the one hand, the surfactants based on C6 fluorocarbon chain, which usually show a better surface activity than surfactants based on $\mathrm{C} 4$ fluorocarbon chain, are regarded as non-bioaccumulable according to current regulations [10], but the studies [38, 112] reveal that the bioaccumulation of surfactants with $\mathrm{C} 4$ fluorocarbon chain is lower and hardly considered. Meanwhile, although fluorine-free surfactants (such as silicon-based surfactants) are also extensively concerned, their performances are not as good as those of fluorinated surfactants $[113,114]$. Therefore, it is an urgent research topic to develop surfactants with shorter fluorocarbon chain and excellent performance. On the other hand, the preparation process of most reported non-bioaccumulable fluorinated surfactants is relatively complicated, which is not conducive to large-scale application. Therefore, simplifying the preparation process and reducing costs are also important directions for subsequent development of non-bioaccumulable fluorinated surfactants. In order to overcome these challenges, researchers still need to make continuous efforts to provide creative answers for the prosperous development of non-bioaccumulable fluorinated surfactants.

\section{Abbreviations}

PFOA: Perfluorooctanoic acid; VDF: Vinylidene fluoride; NaPFO: Sodium perfluorooctanoate; $\gamma_{C M C}$ : Surface tension at CMC; APFO: Ammonium perfluorooctanoate; TFP: 3,3,3-trifluoropropene; CMC: Critical micelle concentration; TFE: Tetrafluoroethylene; PFOS: Perfluorooctane sulfonate; AA: Acrylic acid; APFOS: Ammonium perfluorooctane sulphonate; IVT: In vitro translation; KPFOS: Potassium perfluorooctane sulphonate; SDS: Sodium dodecyl sulfate; PFPE: Poly (perfluoropropylene glycol); SMA: Stearyl methylacrylate; SEM: Scanning electron microscope; PEG: Polyethylene glycol; DFHMA: Dodecafluoroheptyl methacrylate; HPAA: Hydroxypropyl acrylate; DDM: n-dodecyl- $\beta$-D-maltopyranoside; PFA: Perfluoroalkoxy polymer; FEP: Perfluorinated ethylene-propylene copolymer; MMA: Methyl methacrylate; POPs: Persistent organic pollutants; PVDF: Polyvinylidene fluoride; RfAA: $1 \mathrm{H}, 1 \mathrm{H}, 7 \mathrm{H}$-dodecafluoroheptyl methacrylate;

PTFE: Polytetrafluoroethylene; MAF-OH: 3-hydroxy-2-(trifluoromethyl) propanoic acid; PSVNa: Perfluoro (4-methyl-3, 6-dioxaoct-7-ene) sodium sulfonate

\section{Acknowledgements}

This work was supported by the National Natural Science Foundation of China (No.22078207), the Sichuan Science and Technology Program (No. 2020YFG0069), and the Fundamental Research Funds for the Central Universities (China).

\section{Authors' contributions}

RZ: designing the outline, writing this review article; YJ: revising the language and logic; YS, PZ and YZ: collecting references, proposing opinions. The author(s) read and approved the final manuscript.

\section{Funding}

National Natural Science Foundation of China (No.22078207); Sichuan Science and Technology Program (No. 2020YFG0069); Fundamental Research Funds for the Central Universities (China).

\section{Availability of data and materials}

Not applicable.

\section{Competing interests}

The authors declare that they have no competing interests.

Received: 4 August 2020 Accepted: 22 December 2020 Published online: 15 March 2021

\section{References}

1. Zhang Q, Li L, Li Y, et al. Surface wetting-driven separation of surfactantstabilized water-oil emulsions. Langmuir. 2018;34(19):5505-16.

2. Li GL, Zheng LQ, Xiao JX. Synthesis and surface activities of organic solventsoluble fluorinated surfactants. J Fluor Chem. 2009;130(7):674-81. 
3. Grządka E, Matusiak J, Stankevic M. Interactions between fluorocarbon surfactants and polysaccharides. J Mol Liq. 2019;283:81-90.

4. Yoshimura T, Ohno AA, Esumi K. Equilibrium and dynamic surface tension properties of partially fluorinated quaternary ammonium salt gemini surfactants. Langmuir. 2006;22(10):4643-8.

5. Peng S, Hung M. Fluorinated sulfonate surfactants. J Fluor Chem. 2012;133: 77-85.

6. Kovalchuk NM, Trybala A, Starov V, Matarc O, Ivanovad N. Fluoro- vs hydrocarbon surfactants: why do they differ in wetting performance? Adv Colloid Interfac. 2014:210:65-71.

7. Czajka A, Hazell G, Eastoe J. Surfactants at the design limit. Langmuir. 2015 31:8205-17.

8. Rigano L, Savonelli S, Bencini PL. Use and properties of perfluoropolymethyl-isopropylethers in skin and hair cleaning; system stabilization and interference with sebum redistribution on skin and hair. Int J Cosmetic Sci. 1989;11(6):259-82.

9. Fisicaro E, Contardi L, Compari C, et al. Solution thermodynamics of highly fluorinated gemini bispyridinium surfactants for biomedical applications. Colloid Surface A. 2016;507:236-42.

10. Krafft MP, Riess JG. Per- and polyfluorinated substances (PFASs): environmental challenges. Curr Opin Colloid In Sci. 2015;20:192-212.

11. Cai Y, Chen D, Li N, et al. Superhydrophobic metal-organic framework membrane with self-repairing for high-efficiency oil/water emulsion separation. ACS Sustain Chem Eng. 2018;7(2):2709-17.

12. Peng Y, Lu F, Tong Q. One-step synthesis, wettability and foaming properties of high-performance non-ionic hydro-fluorocarbon hybrid surfactants. Appl Surf Sci. 2018;433:264-70.

13. Jia X, Bo H, He Y. Synthesis and characterization of a novel surfactant used for aqueous film-forming foam extinguishing agent. Chem Pap. 2019;73(7): 1777-84.

14. He YH, Sun Q, Xing H. Cationic-anionic fluorinated surfactant mixtures based on short fluorocarbon chains as potential aqueous film-forming foam. J Disper Sci Technol. 2019;40(3):319-31.

15. Yang Y, Ou J, Lv X, et al. Fluorinated polyethylene glycol as cathode interlayer with enhanced dipole strength for efficient organic solar cells. Sol Energy. 2019;180:57-62.

16. Krafft MP. Fluorocarbons and fluorinated amphiphiles in drug delivery and biomedical research. Adv Drug Deliver Rev. 2001;47(2):209-28,

17. Giesy JP, Kannan K. Peer reviewed: perfluorochemical surfactants in the environment. Environ Sci Technol. 2002;36:146A-52A.

18. Mejiaavendano S, Duy SV, Sauve S, Liu J. Generation of perfluoroalkyl acids from aerobic biotransformation of quaternary ammonium polyfluoroalkyl surfactants. Environ Sci Technol. 2016;50(18):9923-32.

19. Wang $T$, Wang $Y$, Liao $C$, et al. Perspectives on the inclusion of perfluorooctane sulfonate into the Stockholm convention on persistent organic pollutants. Environ Sci Technol. 2009;43(14):5171-5.

20. Zaggia A, Ameduri B. Recent advances on synthesis of potentially nonbioaccumulable fluorinated surfactants. Curr Opin Colloid In. 2012;17(4):188-95.

21. Midasch O, Drexler H, Hart N, Beckmann MW, Angerer J. Transplacental exposure of neonates to perfluorooctanesulfonate and perfluorooctanoate: a pilot study. Int Arch Occ Env Hea. 2007;80(7):643-8.

22. Olsen GW, Burris JM, Ehresman DJ, Froehlich JW, Seacat AM, Butenhoff JL, Zoble LR. Half-life of serum elimination of perfluorooctanesulfonate, perfluorohexanesulfonate, and perfluorooctanoate in retired fluorochemical production workers. Environ Health Perspect. 2007;115(9):1298-305.

23. Glynn A, Berger U, Bignert A, et al. Perfluorinated alkyl acids in blood serum from primiparous women in Sweden: serial sampling during pregnancy and nursing, and temporal trends 1996-2010. Environ Sci Technol. 2012;46(16): 9071-9.

24. Wang Z, Cousins IT, Scheringer M, Hungerbuhler K. Fluorinated alternatives to long-chain perfluoroalkyl carboxylic acids (PFCAs), perfluoroalkane sulfonic acids (PFSAs) and their potential precursors. Environ Int. 2013;60:242-8.

25. Sha $M$, Xing $P$, Jiang B. Strategies for synthesizing non-bioaccumulable alternatives to PFOA and PFOS. Chinese Chem Lett. 2015;26(5):491-8.

26. Kostov $G$, Boschet $F$, Ameduri B. Original fluorinated surfactants potentially non-bioaccumulable. J Fluor Chem. 2009;130(12):1192-9.

27. Verdia P, Gunaratne HQ, Goh TY. A class of efficient short-chain fluorinated catanionic surfactants. Green Chem. 2016;18(5):1234-9.

28. Zhang $L$, Geng $B$, Lu Q, et al. Synthesis and surface activities of novel succinic acid double-tailed sulfonate fluorinated surfactants. J Surfactant Deterg. 2016;19(3):559-65.
29. Zhang $\mathrm{D}$, Sha $\mathrm{M}$, Pan $\mathrm{R}$, et al. $\mathrm{CF}_{3} \mathrm{CF}_{2} \mathrm{CF}_{2} \mathrm{C}\left(\mathrm{CF}_{3}\right)_{2}$-based fluorinated surfactants with high surface activity. Chem Pap. 2019;73(6):1499-508.

30. Lapčík J, Gimello O, Ladmiral V, et al. A new oligo (hexafluoropropylene oxide)-b-oligo (ethylene oxide) diblock surfactant obtained by radical reactions. Polym Chem. 2015;6(1):79-96.

31. Shinoda K, Hato M, Hayashi T. Physicochemical properties of aqueous solutions of fluorinated surfactants. J Phys Chem. 1972;76(6):909-14.

32. Chang SC, Noker PE, Gorman GS. Comparative pharmacokinetics of perfluorooctanesulfonate (PFOS) in rats, mice, and monkeys. Reprod Toxicol. 2012;33(4):428-40.

33. Ohmori K, Kudo N, Katayama K. Comparison of the toxicokinetics between perfluorocarboxylic acids with different carbon chain length. Toxicology. 2003;184(2-3):135-40.

34. Butenhoff JL, Kennedy GL Jr, Hinderliter PM, et al. Pharmacokinetics of perfluorooctanoate in cynomolgus monkeys. Toxicol Sci. 2004;82(2):394-406

35. Russell MH, Himmelstein MW, Buck RC. Inhalation and oral toxicokinetics of 6: 2 FTOH and its metabolites in mammals. Chemosphere. 2015;120:328-35.

36. Chengelis CP, Kirkpatrick JB, Myers NR, et al. Comparison of the toxicokinetic behavior of perfluorohexanoic acid (PFHXA) and nonafluorobutane-1sulfonic acid (PFBS) in cynomolgus monkeys and rats. Reprod Toxicol. 2009; 27(3-4):400-6.

37. Russell MH, Nilsson $H$, Buck RC. Elimination kinetics of perfluorohexanoic acid in humans and comparison with mouse, rat and monkey. Chemosphere. 2013;93(10):2419-25.

38. Olsen GW, Chang SC, Noker PE. A comparison of the pharmacokinetics of perfluorobutanesulfonate (PFBS) in rats, monkeys, and humans. Toxicology. 2009;256(1-2):65-74.

39. EFSA Panel on food contact materials, enzymes, flavourings and processing aids (CEF). Scientific Opinion on the safety evaluation of the substance, $3 \mathrm{H}$ perfluoro-3-[(3-methoxy-propoxy) propanoic acid], ammonium salt, CAS No. 958445-44-8, for use in food contact materials. EFSA J. 2011;9(6):2182.

40. Fitzgerald NJ, Wargenau A, Sorenson C, et al. Partitioning and accumulation of perfluoroalkyl substances in model lipid bilayers and bacteria. Environ Sci Technol. 2018;52(18):10433-40.

41. Schuster T, Krumpfer JW, Schellenberger S, et al. Effects of chemical structure on the dynamic and static surface tensions of short-chain, multiarm nonionic fluorosurfactants. J Colloid Interf Sci. 2014;428:276-85.

42. Lehanine Z, Badache L. Effect of the molecular structure on the adsorption properties of cationic surfactants at the air-water interface. J Surfactant Deterg. 2016;19(2):289-95.

43. Dong B, Li N, Zheng L, et al. Surface adsorption and micelle formation of surface active ionic liquids in aqueous solution. Langmuir. 2007;23(8):4178-82.

44. Vijaykumar BVD, Premkumar B, Jang K, Choi Bl, Falck JR. Environmentally benign perfluorooctanesulfonate alternatives using a $\mathrm{Zn} / \mathrm{Cul}$ mediated Michael-type addition in imidazolium ionic liquids. Green Chem. 2014;16(5): 2406-10.

45. Kang E, Jung GY, Jung SH, Lee BM. Synthesis and surface active properties of novel anionic surfactants with two short fluoroalkyl groups. J Ind Eng Chem. 2018:61:216-26.

46. Kateb ME, De Givenchy ET, Baklouti A, Guittard F. Synthesis and surface properties of semi-fluorinated gemini surfactants with two reactive bromo pendant groups. J Colloid Interf Sci. 2011;357(1):129-34.

47. Kang E, Sohn E, Jung GY, Jung SH. Synthesis, interfacial property, and application of new hybrid anion surfactant containing fluorocarbon and hydrocarbon chains. J Ind Eng Chem. 2018;67:72-9.

48. Yang M, Hao J, Li H. Syntheses and aggregation behavior of pyridine-based CH-CF hybrid surfactants. J Fluor Chem. 2014;165:81-90.

49. Bodduri VDV, Chirumarry S, Lim JM, Lee Y, Jang K, Choi B. Synthesis and properties of hemifluorinated disodium alkanesulfonates. J Fluor Chem. 2014;163:42-5.

50. Chirumarry S, Rao VR, Ko Y, Vijaykumar BVD, Lim J. Design, synthesis and surfactant properties of perfluorobutyl-based fluorinated sodium alkanesulfonates. J Fluor Chem. 2017;197:111-7.

51. Ji S, Shen W, Chen L, Zhang Y, Wu X. Synthesis and properties of alkoxyethyl 2acetamido-2-deoxy-a-D-glucopyranoside. J Mol Liq. 2017;242:1169-75.

52. Wang M, Kong S, Liu S, Li C, Wang M, Tan Y. Aggregation behavior of partially fluorinated Gemini surfactants in aqueous solution: effect of headgroups. Colloid Surface A. 2014:441:25-33.

53. Brycki BE, Kowalczyk IH, Szulc A, Kaczerewska O, Pakiet M. Multifunctional gemini surfactants: structure, synthesis, properties and applications. Appl Characterization Surfactants. 2017. https://doi.org/10.5772/intechopen.68755. 
54. Lv Y, Chen L, Liu H, Zhang S, Wang M, Tan Y. Surface activity properties and aggregation behaviors of partially fluorinated gemini surfactants in aqueous solution. J Surfactant Deterg. 2017;20(3):543-52.

55. Quagliotto P, Barolo C, Barbero N, Barni E, Compari C, Fisicaro E, Viscardi G. Synthesis and characterization of highly fluorinated gemini pyridinium surfactants. Eur J Org Chem. 2009;2009(19):3167-77.

56. Asakawa T, Amada AK, Miyagishi S. Micellar immiscibility of lithium 1,1,2,2tetrahydroheptadecafluorodecyl sulfate and lithium tetradecyl sulfate mixture. Langmuir. 1997;13(17):4569-73.

57. Woch J, Hordyjewiczbaran Z, Kuliszewska E, Cegielska A, Otulakowski S, Dworak A, Trzebicka B. Self-organization and solubilization properties of gemini hydrotropic compounds in aqueous solution. Colloid Surface A. 2016:506:264-75.

58. Nakahara H, Nishino A, Tanaka A, Fujita Y, Shibata O. Interfacial behavior of gemini surfactants with different spacer lengths in aqueous medium. Colloid Polym Sci. 2019;297(2):183-9.

59. Fisicaro E, Compari C, Bacciottini F, Contardi L, Barbero N, Viscardi G. Nonviral gene delivery: gemini bispyridinium surfactant-based DNA nanoparticles. J Phys Chem B. 2014;118(46):13183-91.

60. Shen Y, Jin Y, Lai S, Shi L, Du W, Zhou R. Synthesis, surface properties and cytotoxicity evaluation of nonionic urethane fluorinated surfactants with double short fluoroalkyl chains. J Mol Liq. 2019;296:111851.

61. Francis DV, Miles DH, Mohammed Al, Read RW, Wang X. Towards functional fluorous surfactants. Synthesis of hydrophilic fluorous 1,2,3triazolylmethyl ethers and di (1,2,3-triazoly|methyl) ethers. J Fluor Chem. 2011;132(11):898-906.

62. Bongartz N, Patil SR, Stubenrauch C, Blunk D. A new fluorinated inositolbased surfactant. Colloid Surface A. 2012:414:320-6.

63. Boussambe GN, Guillet P, Mahler F, Marconnet A, Vargas C, Cornut D. Fluorinated diglucose detergents for membrane-protein extraction. Methods. 2018;147:84-94.

64. Ji S, Shen W, Chen L, Zhang Y, Wu X, Fan Y. Synthesis and properties of sugar-based surfactants alkoxyethyl $\beta$-D-glucopyranoside. Colloid Surface A. 2019;564:59-68.

65. Blunk D, Bongartz N, Stubenrauch C, Gärtner V. Syntheses, amphitropic liquid crystallinity, and surface activity of new inositol-based amphiphiles. Langmuir. 2009;25:7872-8.

66. Kissa E. Fluorinated surfactants and repellents. New York: CRC Press; 2001.

67. Yin Q, Xue W, Bai Y, Wang W, Ma X, Du Z, Wang G. Micellization and aggregation properties of sodium perfluoropolyether carboxylate in aqueous solution. J Ind Eng Chem. 2016;42:63-8.

68. Shen J, Bai Y, Yin Q, Wang W, Ma X, Wang G. Adsorption, aggregation and wetting behaviors of biodegradable surfactant: Perfluoropolyether quaternary ammonium salt. J Ind Eng Chem. 2017;56:82-9.

69. Shen J, Bai Y, Tai X, Wang W, Wang G. Surface activity, spreading, and aggregation behavior of ecofriendly perfluoropolyether amide propyl betaine in aqueous solution. ACS Sustain Chem Eng. 2018;6(5):6183-91.

70. Krafft MP, Chittofrati A, Riess JG. Emulsions and microemulsions with a fluorocarbon phase. Curr Opin Colloid In. 2003;8(3):251-8

71. Sadtler VM, Krafft MP, Riess JG. Achieving stable, reverse water-influorocarbon emulsions. Angew Chem Int Edit. 1996;35(17):1976-8.

72. Holtze C, Rowat AC, Agresti JJ, Hutchison JB, Angile FE, Schmitz C. Biocompatible surfactants for water-in-fluorocarbon emulsions. Lab Chip. 2008;8(10):1632-9.

73. Wagner O, Thiele J, Weinhart M, Mazutis L, Weitz DA, Huck TS, Haag R. Biocompatible fluorinated polyglycerols for droplet microfluidics as an alternative to PEG-based copolymer surfactants. Lab Chip. 2015;16(1):65-9.

74. Boutevin G, Tiffes D, Loubat C, Boutevin B, Ameduri B. New fluorinated surfactants based on vinylidene fluoride telomers. J Fluor Chem. 2012;134: 77-84.

75. Ameduri B, Ladavière C, Delolme F, Boutevin B. First MALDI-TOF mass spectrometry of vinylidene fluoride telomers endowed with low defect chaining. Macromolecules. 2004;37(20):7602-9.

76. Boyer C, Valade D, Sauguet L, Ameduri B, Boutevin B. Iodine transfer polymerization (ITP) of vinylidene fluoride (VDF). Influence of the defect of VDF chaining on the control of ITP. Macromolecules. 2005;38(25):10353-62.

77. Durand N, Ameduri B, Boutevin B. Synthesis and characterization of functional fluorinated telomers. J Polym Sci Pol Chem. 2011:49(1):82-92.

78. Griffiths PC, Cheung AYF, Jenkins RL, Howe AM, Pitt AR, Heenan PK, King SM. Interaction between a partially fluorinated alkyl sulfate and gelatin in aqueous solution. Langmuir. 2004;20(4):1161-7.
79. Yake A, Corder T, Moloy K, Coope T, Taylor C, Hung M, Peng S. Fluorinated pyridinium and ammonium cationic surfactants. J Fluor Chem. 2016;187:4655.

80. Zhang L, Liu Z, Ren T, Wu P, Shen J, Zhang W, Wang X. Understanding the structure of hydrophobic surfactants at the air/water interface from molecular level. Langmuir. 2014;30(46):13815-22.

81. Wu H, Zhong J, Shen H, Shi H. Synthesis of a novel branch fluorinated cationic surfactant and its surface activity. J Fluor Chem. 2013;156(156):5-8

82. Chen L, Shi H, Wu H, Xiang J. Synthesis and combined properties of novel fluorinated anionic surfactant. Colloid Surface A. 2011;384(1-3):331-6.

83. Zhang Q, Luo Z, Curran DP. Separation of "light fluorous" reagents and catalysts by fluorous solid-phase extraction: synthesis and study of a family of triarylphosphines bearing linear and branched fluorous tags. J Org Chem. 2000;65(26):8866-73.

84. Lin C, Pan R, Xing P, Jiang B. Synthesis and surface activity study of novel branched zwitterionic heterogemini fluorosurfactants with $\mathrm{CF}_{3} \mathrm{CF}_{2} \mathrm{CF}_{2} \mathrm{C}\left(\mathrm{CF}_{3}\right)_{2}$ group. J Fluor Chem. 2018;214:35-41.

85. Sha $M$, Pan $R$, Xing $P$, Jiang $B$. Synthesis and surface activity study of branched fluorinated cationic (FCS), gemini (FGS) and amphoteric (FAS) surfactants with $\mathrm{CF}_{3} \mathrm{CF}_{2} \mathrm{CF}_{2} \mathrm{C}\left(\mathrm{CF}_{3}\right)_{2}$ group. J Fluor Chem. 2015;169:61-5.

86. Lin C, Pan R, Xing P, Jiang B. Synthesis and combined properties of novel fluorinated cationic surfactants derived from hexafluoropropylene dimer. Chin Chem Lett. 2018;29(11):1613-6.

87. Zhang $D$, Sha $M$, Pan $R$, Lin $X$, Xing $P$, Jiang $B$. Design and synthesis of the novel branched fluorinated surfactant intermediates with $\mathrm{CF}_{3} \mathrm{CF}_{2} \mathrm{CF}_{2} \mathrm{C}\left(\mathrm{CF}_{3}\right)_{2}$ group. Chin Chem Lett. 2019;30(3):566-8.

88. Zhang $D$, Sha $M$, Pan $R$, Lin $X$, Xing $P$, Jiang $B$. Synthesis and properties study of novel fluorinated surfactants with perfluorinated branched ether chain. J Fluor Chem. 2019;219:62-9.

89. Wei Z, Chen X, Duan J, Zhan G, Wei Y, Zhang A. Branched chain versus straight chain fluorinated surfactant: a comparative study of their anticorrosion performance on carbon steel. J Mol Liq. 2019;280:327-33.

90. Sharma SC, Kunieda H, Esquena J, Abreu CR. Phase behavior and preparation of mesoporous silica in aqueous mixtures of fluorinated surfactant and hydrophobic fluorinated polymer. J Colloid Int Sci. 2006;299(1):297-304.

91. Prevedouros K, Cousins IT, Buck RC, Korzeniowski SH. Sources, fate and transport of perfluorocarboxylates. Environ Sci Technol. 2006;40(1):32-44.

92. Ameduri B, Boutevin B. Well-architectured fluoropolymers: synthesis, properties and applications. Amsterdam: Elsevier; 2004.

93. Banerjee S, Schmidt J, Talmon Y, Hori H, Asai T, Ameduri B. A degradable fluorinated surfactant for emulsion polymerization of vinylidene fluoride. Chem Commun. 2018;54(81):11399-402.

94. Zhao M, Yu Y, Han Z, Li H. Preparation of a fluorocarbon polymerizable surfactant and its application in emulsion polymerization of fluorine-containing acrylate. Polymers. 2017;9(11):606.

95. Popot J. Amphipols, nanodiscs, and fluorinated surfactants. Three nonconventional approaches to studying membrane proteins in aqueous solutions. Annu Rev Biochem. 2010;79(1):737-75.

96. Breyton C, Gabel F, Abla M, Pierre Y, Lebaupain F, Durand G. Micellar and biochemical properties of (hemi) fluorinated surfactants are controlled by the size of the polar head. Biophys J. 2009;97(4):1077-86.

97. Lebaupain F, Salvay AG, Olivier B, Durand G, Fabiano A, Michel N. Lactobionamide surfactants with hydrogenated, perfluorinated or hemifluorinated tails: physical-chemical and biochemical characterization. Langmuir. 2006:22(21):8881-90.

98. Sharma KS, Durand G, Giusti F, Olivier B, Fabiano A, Bazzacco P. Glucosebased amphiphilic telomers designed to keep membrane proteins soluble in aqueous solutions: synthesis and physicochemical characterization. Langmuir. 2008;24(23):13581-90.

99. Guillet P, Mahler F, Garnier K, Boussambe GNM. Hydrogenated diglucose detergents for membrane-protein extraction and stabilization. Langmuir. 2019;35(12):4287-95.

100. Abla M, Durand G, Breyton C, Raynal S, Ebel C, Pucci B. A diglucosylated fluorinated surfactant to handle integral membrane proteins in aqueous solution. J Fluor Chem. 2012;134:63-71.

101. Abla M, Unger S, Keller S, Bonnete F, Ebel C, Pucci B. Micellar and biochemical properties of a propyl-ended fluorinated surfactant designed for membrane-protein study. J Colloid Int Sci. 2015:445:127-36.

102. Legrand F, Breyton C, Guillet P, Ebel C, Durand G. Hybrid fluorinated and hydrogenated double-chain surfactants for handling membrane proteins. J Org Chem. 2016;81(2):681-8. 
103. Polidori A, Raynal S, Barret L, Dahani M, Barrotivolot C, Jungas C. Sparingly fluorinated maltoside-based surfactants for membrane-protein stabilization. New J Chem. 2016;40(6):5364-78.

104. Frotscher E, Danielczak B, Vargas C, Meister A, Durand G, Keller S. A fluorinated detergent for membrane-protein applications. Angew Chem Int Edit. 2015;54(17):5069-73.

105. Segal L, Philips FJ, Loeb L, Clayton RL. Oil and water repellent treatments for cotton with fluorochemicals1. Text Res J. 1958;28(3):233-41.

106. Koike N, Sakano Y. New fluorine-containing acetylene alcohol useful as retarder for hydrosilylation curing reaction of highly fluorinated polymers, as nonionic surfactant and as intermediate for chemical synthesis. US2005272948. 2005

107. Sagisaka M, Iwama S, Yoshizawa A, Mohamed A, Cummings S, Eastoe J. Effective and efficient surfactant for CO2having only short fluorocarbon chains. Langmuir. 2012;28(30):10988-96.

108. Shen Y, Jin Y, Lai S, Shi L, Zhou Y, Zhou R. Nonionic short-chain fluorinated surfactants in the fatliquoring of chrome-tanned goat skin. J Am Leather Chem As. 2020;115(7):255-62.

109. Zhang Q, Zhan X, Chen F. Fluorine-containing copolymer water and oil repellent finishing agent composition and its preparation method. CN201310305470; 2013.

110. Zhang Q, Zhan X, Chen F, Luo N, Xiang X, Xu Y, Chen Y. Low-temperature crosslinking fluorine-containing nuclear shell type water-repellent and oilrepellent finishing agent emulsion and preparation method thereof CN201310339072; 2013.

111. Liu S, Qiu-feng AN, Wei XU. Synthesis and application fluorinated polyacrylate emulsifier-free emulsion. Leather Sci Eng. 2011;21(5):46-50 (in Chinese).

112. Newsted JL, Beach SA, Gallagher SP, Giesy JP. Acute and chronic effects of perfluorobutane sulfonate (PFBS) on the mallard and northern bobwhite quail. Arch Environ Con Tox. 2008;54(3):535-45.

113. Bao Y, Guo J, Ma J. Cationic silicon-based gemini surfactants: effect of hydrophobic chains on surface activity, physic-chemical properties and aggregation behaviors. J Ind Eng Chem. 2017;53:51-61.

114. Sheng Y, Jiang N, Lu S. Study of environmental-friendly firefighting foam based on the mixture of hydrocarbon and silicone surfactants. Fire Technol. 2020;56(3):1059-75.

\section{Publisher's Note}

Springer Nature remains neutral with regard to jurisdictional claims in published maps and institutional affiliations.

\section{Submit your manuscript to a SpringerOpen ${ }^{\circ}$ journal and benefit from:}

- Convenient online submission

- Rigorous peer review

- Open access: articles freely available online

- High visibility within the field

- Retaining the copyright to your article

Submit your next manuscript at $\boldsymbol{\nabla}$ springeropen.com 